
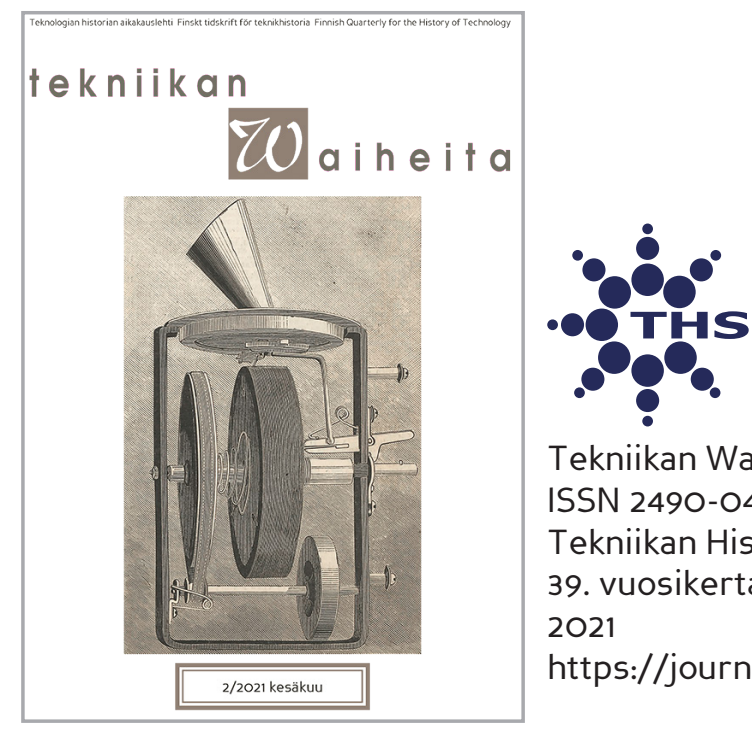

Tekniikan Waiheita

ISSN 2490-0443

Tekniikan Historian Seura ry.

39. vuosikerta: 2

2021

https://journal.fi/tekniikanwaiheita

\title{
Werner Heisenbergin Suomen-kontaktit
}

Tuire Ranta-Meyer

To cite this article: Tuire Ranta-Meyer, "Werner Heisenbergin Suomen-kontaktit" Tekniikan Waiheita 39, no. 2 (2021): 63-86. https://doi.org/10.33355/tw.109430

To link to this article: https://doi.org/10.33355/tw.109430 


\title{
Werner Heisenbergin Suomen-kontaktit
}

\author{
Tuire Ranta-Meyer ${ }^{1}$
}

\section{Johdanto}

Modernin fysiikan suurista nimistä Werner Heisenberg (1901-1976) oli sata vuotta sitten uransa alussa. Hänen läpimurtoartikkelinsa kinemaattisisten ja mekaanisten suhteiden kvanttiteoreettisesta uudelleentulkinnasta oli ensimmäisten joukossa ottamassa ratkaisevaa askelta kohti modernia, edelleenkin voimassa olevaa atomiteoriaa ja kvanttimekaniikkaa. ${ }^{2}$ Artikkeli valmistui kesällä 1925 ja julkaistiin saman vuoden joulukuussa alan keskeisessä tiedelehdessä Zeitschrift für Physik. Heisenberg on monen mielestä se, joka kuvaannollisesti "ratkaisi Gordionin solmun miekaniskulla", vei loppuun Max Planckin, Albert Einsteinin ja muiden aikalaisten kehittelemän kvanttiteorian ja "avasi modernin fysiikan alalla uuden kultaisen aikakauden."

Tässä artikkelissa tarkastelen Werner Heisenbergia ja hänen toimintaansa ennen edellä mainitun artikkelin ilmestymistä. Keskiössä on erityisesti vuosi 1923, jolloin hän väitteli Münchenissä tohtoriksi ja teki sen jälkeen Suo-

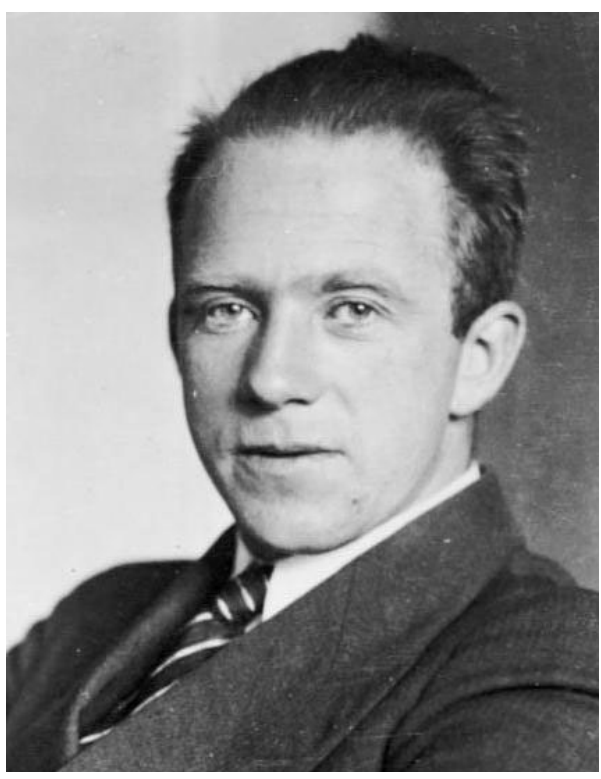

Kuva 1. Werner Heisenberg vuonna 1933. Valokuva Bundesarchiv Bild 183-R57262. Wikipedia Commons. meen kesäretken kymmenhenkisen partiolaisryhmänsä johtajana. Tarkoituksena on tuoda esiin uutta tietoa kohdehenkilöstä: hänen persoonastaan, opinnoistaan sekä niistä kokemuksista, joita hän usean viikon Suomen-matkansa aikana sai. Keitä hän tapasi, mikä tai ketkä tekivät häneen vaikutuksen, mihin hän kiinnitti huomionsa ja miten Suomen-kontaktit jatkuivat hänen elämässään? Mitä tähän asti Suomessa kokonaan tuntemattomaksi jääneet arkistolähteet ja viimeisin elämäkertatutkimus paljastavat tästä modernin fysiikan pioneerista? Onko mahdollista tehdä johtopäätöksiä primaariaineiston - esimerkiksi Heisenbergin suomalaisille lähettämien autenttisten kirjeiden - perusteella hänen ajatuksistaan, asenteistaan tai vaikkapa poliittisista näkemyksistään? ${ }^{4}$

\footnotetext{
${ }^{1}$ FT, MuM Tuire Ranta-Meyer (tuire.ranta-meyer@metropolia.fi) on Erkki Melartin -tutkija ja Suomen musiikinhistorian dosentti. Hän työskentelee yhteistyöstä ja verkostoista vastaavana johtajana Metropoliassa.

2 Saks. "Über quantentheoretische Umdeutung kinematischer und mechanischer Beziehungen".

${ }^{3}$ Ks. esim. Rechenberg 2010, vi. Tässä artikkelissa esiintyvät käännökset alkukielisistä teoksista ja painamattomista lähteistä ovat kirjoittajan.

${ }^{4}$ Kiitän lämpimästi Heinrich Beckeriä käyttööni saamastani aineistosta, kirjeiden kopioista ja vuonna 2019 ilmestyneestä kirjasta.
} 
Valtaosa Heisenbergin elämää ja henkilöä käsittelevästä tutkimuksesta kohdistuu hänen uraansa fyysikkona. Tässä artikkelissa nostan hänet esiin laajemmasta näkökulmasta ja asetan saksalaiseen sadan vuoden takaiseen kontekstiinsa, jossa vaikuttivat niin suuret yhteiskunnalliset murrokset ja hävityn ensimmäisen maailmansodan seuraukset kuin luonnontieteissä tehdyt edistysaskeleet. Mitkä luonteenpiirteet antoivat osviittaa tulevasta menestyksestä tutkijana ja miten lahjakkuus ilmeni? Millaisten elämänarvojen varaan hän rakensi uransa, johon toisen maailmansodan jälkeen kohdistui myös epäilyjä natsisympatioista. Heisenbergia on myöhemmin arvosteltu esimerkiksi siitä, ettei hän monen muun ajankohdan huippunimen tavoin lähtenyt kansallissosialistisesta Saksasta emigrantiksi Yhdysvaltoihin. Hänelle tarjottiin 1930-luvulla kaksikin kertaa sieltä työtehtäviä, mutta hän kieltäytyi molemmilla kerroilla. ${ }^{5}$ Vuonna 1942 Heisenberg kutsuttiin Berliiniin Saksan "uraaniprojektista" eli ydinaseohjelmasta vastanneen kunnianarvoisan, muiden muassa Albert Einsteinin johdolla aiemmin toimineen Kaiser-Wilhelm-Institut für Physikin vetäjäksi. Tästä syystä hänet internoitiin sodan päättymisen jälkeen toukokuussa 1945 kuudeksi kuukaudeksi Englantiin kuulusteluja varten. ${ }^{6}$

Biografisen tutkimuksen metodeihin perustuvan artikkelini taustalla on ajatus vuorovaikutuksesta yleisen ja erityisen välillä. ${ }^{7}$ Yksityisen ihmisen kokemukset ja elämykset ovat nousseet keskeiseksi aineistoksi nykyisessä historiantutkimuksessa, vaikka toisen maailmansodan jälkeen akateeminen maailma suhtautui epäillen henkilöhistoriallisiin aiheisiin ja pyrki leimaamaan ne liian yksikertaiseksi. Kyseessä oli vastareaktio 1930-luvun suurmies- ja johtajapalvonnalle samalla kun rakennehistoria nousi arvostetun metodin asemaan. ${ }^{8}$

Elämäkerrallisen aineiston käyttö on kuitenkin lisääntynyt viimeisten vuosikymmenien aikana erityisesti mikrohistoriallisen tendenssin vuoksi: jotta saisimme aineksia laajemmille johtopäätöksille, tarvitsemme tietoa mahdollisimman monien ihmisten kokemusmaailmasta. Sitä on löydettävissä päiväkirjojen ja kalentereiden lehdiltä, muistelmista ja kirjeistä. Kun halutaan selvittää tiettyyn tutkimuskohteeseen tai ajankohtaan liittyviä tunnelmia, ajatuksia ja näkökulmia, henkilökohtainen aineisto on yksi kaikkein autenttisin lähde. ${ }^{9}$ Mikro- ja elämänhistorioiden esiin nostamat henkilöt ovat sitä paitsi aina yksilöitä, joiden toimintaa ja toimijuutta tutkimalla monet ajankohdan polttavat kysymykset nousevat esiin. Asettamalla eletty elämä tutkimuksen avulla osaksi aikakautensa ilmiöitä ja tarkastelemalla sitä, miten tutkimuksen kohteena olevat itse elinaikanaan ovat ympäristöönsä asettuneet, saadaan uusia näkökulmia ja tutkimustietoa. ${ }^{10}$

\footnotetext{
${ }^{5}$ Hirsch-Heisenberg 2003, 372-374, 378-384. Kirjansa loppuluvussa "Erinnerungen an meinen Vater" HirschHeisenberg pohtii laajasti myös Heisenbergin suhtautumista kansallissosialisteihin ja osuutta uraaniprojektissa. Myös Heisenberg itse käsittelee asiaa useassa luvussa omaelämäkerrassaan Der Teil und das Ganze (1969).

${ }^{6}$ Rechenberg 2010, vii.

${ }^{7}$ Ks. esim. Leskelä-Kärki 2006 ja 2012; Hakosalo, Jalagin, Junila \& Kurvinen 2014.

${ }^{8}$ Kurth \& Soikkanen, 4.

${ }^{9}$ Hietala 2001, 245.

${ }^{10}$ Engman 2000, 249-250; Immonen 2002, 19-20.
} 


\section{Ensimmäisen maailmansodan perintö ja Heisenbergin kasvuvuodet}

Werner Heisenberg eli ja vaikutti neljän eri poliittisen valtiomuodon Saksassa: vuoteen 1918 asti keisarikunnassa, sen jälkeen opiskelijana ja opettajana Weimarin tasavallassa, vuodesta 1933 alkaen Hitlerin kansallissosialistisessa diktatuurissa ja vuoden 1945 jälkeen länsiliittoutuneiden etupiirijaon mukaisessa Länsi-Saksassa. ${ }^{11}$ Hänen koti- ja opiskelukaupunkinsa oli Alppien juurella sijaitseva loistelias, barokin ja uusklassismin leimaama München, jota rikkaan kulttuurin ja taide-elämän vuoksi kutsuttiin vuosisadan vaihteessa "Ateenaksi Isarjoen rannalla". ${ }^{12}$

Kesällä 1914 kruununprinssi Frans Ferdinandin murhasta puhjennut ensimmäinen maailmansota mullisti kuitenkin myös müncheniläisten arjen, vaikka aluksi se oli otettu innostuneesti vastaan ja odotettu sen olevan lyhyt ja voittoisa. Sodan pitkittyminen ja Ison-Britannian saarto olivat johtaneet monenlaiseen kärsimykseen: tavara- ja elintarvikepulaan, säännöstelyyn, korviketuotteetteisiin ja neljännesmiljoonan saksalaisen kuolemaan aliravitsemuksen takia. Erityisen vaikea oli niin sanottu nälkätalvi 1917 ja 1918 (Hungerwinter, Kohlrübenwinter), jolloin siviiliväestöllä ei ollut juuri muuta syötävää kuin lanttua. Myös lukioikäinen Heisenberg oli tuolloin niukan ravinnon niin heikentämä, että vanhemmat katsoivat parhaaksi lähettää hänet kesäksi 1918 maatilalle aputöihin. Työtä oli tehtävä ahkerasti aikaisesta aamusta auringonlaskuun asti, mutta vastapainoksi tarjolla oli kunnollista ruokaa. "Opin siellä uurastamaan", Heisenberg kertoi myöhemmin lapsilleen ja jatkoi: "Uskon, että lopulta tuo oli minulle yksi tärkeimmistä ajoista opintojani ajatellen, sillä maatilalla todella oppi tekemään työtä. Se oli toista kuin koulunkäynti, jota nuorena ei pidä niin tärkeänä."13

Kun sota vuonna 1918 päättyi antautumiseen, hinta sen aloittaneelle Saksalle oli suunnaton: noin kaksi miljoonaa kaatunutta, viisi miljoonaa haavoittunutta, talous ja infrastruktuuri raunioina ja lisäksi kansalaisten täysin menettämä luottamus auktoriteetteihin. Häviö oli tullut tavallisille saksalaisille yllätyksenä, koska informaatiota sodan todellisesta tilasta oli sensuroitu kansan taistelusitkeyden ylläpitämiseksi. ${ }^{14}$ Versaillesin rauhansopimuksen myötä Saksa menetti alueitaan, väestöään ja käytännössä koko sotavoimansa lukuun ottamatta pientä joukkoa. Se joutui tunnustamaan syyllisyytensä sotaan ja maksamaan suuret sotakorvaukset. Monille saksalaisille kyseessä oli "häpeärauha" ja kansallinen nöyryytys, mihin kansallissosialistit osasivat myöhemmin valtapyrkimyksissään taitavasti vedota. ${ }^{15}$

Syksyllä 1918 Saksasta tehtiin parlamentaarinen demokratia. Maa ajautui kuitenkin kaaokseen sitä mukaa, kun joukot palasivat rintamalta. Sota oli vammauttanut henkisesti ja fyysisesti monia sotilaita ja totuttanut heidät väkivaltaan, johon turvauduttiin myös rauhan palattua. ${ }^{16}$ Vasemmiston ja oikeiston välillä puhkesi verisiä yhteenottoja, mutta myös sosialistinen puolue jakautui kahtia. Kommunistit tukivat radikaaleja spartakisteja, joiden tavoitteena oli sosialistinen vallankumous.

Vuoden 1918 lopussa sekasorto oli levinnyt myös 17-vuotiaan Heisenbergin kotikaupunkiin. Useat väkivaltaiset yritykset saada aikaan vallankumous jatkuivat, ja esimerkiksi

\footnotetext{
${ }^{11}$ Rechenberg 2010, vii.

12 King 2016, 29-30.

13 Sit. Cassidy 1992, 34-36.

14 Hett 2019, 36-65.

15 King 2016, 30-31.

16 Hett 2019, 36-37.
} 
juuri München julistautui hetkellisesti neuvostotasavallaksi. Kapina kuitenkin murskattiin keväällä 1919 armeijan ja eräänlaisten puolisotilaallisten joukkojen (Freikorps) avulla. ${ }^{17}$

Ensimmäinen maailmansota, elintarvikepula, pelko sosialistisesta vallankumouksesta ja Weimarin tasavallan dramaattiset alkuaskeleet eivät menneet teini-ikäisen Heisenbergin ohi huomaamatta. Osa opettajista ja monet 16-18-vuotiaat koulutoverit olivat joutuneet armeijaan. Oppitunteja lyhennettiin, ja muiden ylempien kouluasteiden tavoin myös Münchenin Maximilians-lyseoon perustettiin opettaja, tohtori Ernst Kemmerin johdolla tapahtuvaa Wehrkraftverein-toimintaa. Maaliskuussa 1915 myös Werner Heisenberg liittyi tähän eräänlaiseen leikin varjolla sotaan tai sotaväkeen valmentavaan yhdistykseen tai "alokasesikouluun", jossa harjoiteltiin käytännön taitoja suunnistuksesta maastoutumiseen, liputusmerkeistä kädentaitoihin sekä perunoiden kuorimisesta ja retkiaterian valmistamisesta aseiden käsittelyyn. ${ }^{18}$

Kyse ei ollut kuitenkaan varsinaisesta sotilaallisesta koulutuksesta, ja ainakin Heisenbergin opettaja Kemmer pohti tunnontarkasti tällaisen toiminnan soveltumista koulun kasvatustehtävään. ${ }^{19}$ On myös muistettava, että tuolloin poikien kasvatus- ja leikkimiskulttuuriin kuuluivat intiaani-, väijytys- ja sotaleikit, tinasotamiehet ja sotaan liittyvien pienoismallien rakentelu. Kansallisylpeys, isänmaallisuus ja asekuntoisuus, jopa sodan ihannoiminen, olivat lisäksi keisariaikana monien saksalaislasten normaali kasvualusta. Heisenbergin kielitieteilijäisä ei kuitenkaan vaikuta siirtäneen tällaisia ihanteita poikiinsa: Wehrkraftvereinin (WKV) osasto 18B:hen liittyminen oli silloiselle14-vuotiaalle Wernerille pikemminkin siirtymäriitti lapsuudesta uuteen elämänvaiheeseen ja irtautumista kodin piiristä muiden saman ikäisten pariin. Nähtävästi tunnollisen luonteensa ja ongelmaratkaisutaitojensa johdosta hänet nimitettiin syyskuussa 1918 WKV-osastonsa yhdeksi ryhmänjohtajaksi. ${ }^{20}$

\section{Maximilians-lukiosta Ludwig-Maximilians-yliopistoon}

Kouluaikana fysiikka ja erityisesti matematiikka olivat tulevan nobelistin vahvimmat aineet. Niissä hän oli ylioppilaaksi kirjoittaessaan jo huomattavasti edellä ikätovereitaan. Hänen ylioppilastutkintonsa sensori, tohtori Johannes Melber, tiivisti vuonna 1920 arvionsa tästä Maximilians-Gymnasiumin eliittioppilaasta seuraavasti: "Heisenberg on kautta linjan erittäin lahjakas, mutta aivan huomattavan etevä hän on matemaattis-luonnontieteellisissä oppiaineissa. Kun tämä ylioppilas nyt haluaa omistautua matematiikan opinnoille ja kun häneltä varmasti voidaan odottaa tämän alan parissa oivallisia tuloksia, voidaan hänen ottamistaan Maximilianeumiin siitä syystä hartaasti suositella." ${ }^{21}$ Melber itse oli kielten opettaja, mutta tiesi fysiikan aineenopettajan antaneen kirjoituksissa ja suullisessa tentissä oppilaalleen eri-

\footnotetext{
${ }^{17}$ Mt., 50-53; Rechenberg 2010, 34-35.

${ }^{18}$ Becker 2019, 11-21; Rechenberg 2010, 31.

${ }^{19}$ Becker 2019, 12-13.

${ }^{20}$ Mt., 1, 11.

21 "Heisenberg ist durchweg sehr gut begabt, ganz hervorragend aber für die mathematisch physikalischen Disziplinen. Da der Schüler sich dem Studium der Mathematik widmen will und mit Sicherheit erwartet werden darf, dass er auf diesem Gebiet einmal Vorzügliches leisten wird, kann ich für ihn die Aufnahme in das Maximilianeum angelegentlich empfehlen." Huom! Maximilianeum oli säätiö, joka mahdollisti lahjakkaille yliopisto-opiskelijoille asumisen ja ylläpidon upeassa uusrenessanssipalatsissa, jossa nykyään toimii Baijerin liittovaltion hallitus.
} 
tyisen vaikeita tehtäviä, joiden itsenäinen ratkaiseminen osoitti tämän olevan matematiikassa ja fysiikassa paljon koulussa edellytetyn tason yläpuolella. ${ }^{22}$

Alun perin Heisenbergin tarkoitus oli ryhtyä opiskelemaan matematiikkaa Münchenin Ludwig-Maximilians-yliopistossa. Hän oli erityisen kiinnostunut lukuteoriasta ja pyrki siksi suoraan kunnianarvoisan, $\pi: n$ transsendenttiaalisuuden todistaneen matematiikan professori Ferdinand von Lindemannin (1852-1939) seminaariin. Se oli melko ennenkuulumatonta vasta opintonsa aloittavan kohdalla, mutta nuori mies oli itsevarma ja luotti tekevänsä vaikutuksen matematiikan professoriin päästessään tapaamaan tätä henkilökohtaisesti. Omaelämäkerrassaan Heisenberg kuvaa, miten hullunkurisen totaalisesti keskustelu epäonnistui. ${ }^{23}$ Ennen kuin sanaakaan oli vaihdettu, jo hieman väsähtäneen oloisen professorin pieni musta koira alkoi räksyttää, eikä lopettanut koko aikana, vaan yltyi haukkumaan yhä hysteerisemmin. Hämmentynyt fuksi alkoi takellella puheessaan eikä pystynyt vakuuttamaan erityisosaamisellaan. Kaiken kukkuraksi hän erehtyi mainitsemaan Lindemannille lukeneensa äskettäin yleiseen suhteellisuusteoriaan liittyvää Hermann Weylin teosta Raum, Zeit, Materie (1918), jolloin professori päätti välittömästi keskustelun sanoen kategorisesti: "Siinä tapauksessa olette matematiikkaa ajatellen jo turmeltunut." ${ }^{24}$

Heisenberg otti tämän epäonnistumisen raskaasti. Hän olisi voinut etsiytyä jonkun toisen matematiikan professorin oppiin, mutta isänsä kanssa keskusteltuaan hän päätti vaihtaa pääainetta ja pyrkiä teoreettiseen fysiikkaan. Onnekkaasti siinä professorina oli kokenut, ammattipiireissä erittäin arvostettu ja opettajaominaisuuksiltaan loistava Arnold Sommerfeld (1868-1951). Miltei 70-vuotiaaseen Lindemanniin verrattuna tämä silloin 51-vuotias fyysikko tuntui Heisenbergistä todelliselta nuorten ystävältä. Vaikka ensivaikutelma antoi Sommerfeldista ankaran kuvan, 19-vuotiaan nuoren käsitys muuttui nopeasti: "Jo ensimmäisistä lauseista alkaen tuntui, kuin välitön hyvyys puhuisi, hyväntahtoisuus sellaista nuorta ihmistä kohtaan, joka tuossa tilanteessa etsi ohjausta ja neuvoja." ${ }^{25}$ Toisin kuin Lindemannia, Weylin kirjan mainitseminen innosti Sommerfeldia, ja keskustelun päätteeksi oli selvää, että nuori Heisenberg pääsisi erityistapauksena Sommerfeldin oppilaaksi. ${ }^{26}$

Sattumalla oli siis osuutensa siinä, että Heisenberg aloitti opinnot juuri Arnold Sommerfeldin kaltaisen tiedemiehen kanssa ja sai tältä syvällisiä vaikutteita. Sommerfeld tunsi modernia fysiikkaa, oli itse henkilökohtaisesti tehnyt alalla merkittäviä tieteellisiä löytöjä ja törmännyt niiden yhteydessä niin suhteellisuusteoriaan kuin kvanttimekaniikkaankin. Hänen luokallaan ensimmäisen vuoden yliopisto-opiskelija Heisenberg pääsi yhtäältä etuoikeutettujen joukkoon, mutta toisaalta professori vaati erinomaisia suorituksia niiltä, jotka aikoivat tehdä hänen ohjauksessaan väitöskirjan. ${ }^{27}$

Heisenberg väitteli tohtoriksi vain 21-vuotiaana heinäkuussa 1923 aivan muusta kuin atomifysiikasta. Hän oli ollut Sommerfeldin jalanjäljissä kiinnostunut juuri siitä ja jo alkuvuodesta 1922 alkaen julkaissut yksin tai yhdessä professorinsa kanssa tutkimusartikkeleita

\footnotetext{
22 Rechenberg 2010, 38-39, 68.

${ }^{23}$ Heisenberg 1971, 15-16.

24 "Dann sind Sie für die Mathematik sowieso schon verdorben."

25 "Aber schon aus den ersten Sätzen schien mir eine Güte zu sprechen, ein Wohlwollen für den jungen Menschen, der hier Führung und Rat suchte." Ks. Rechenberg 2010, 68-70.

${ }^{26}$ Rechenberg 2010, 71; Heisenberg 1971, 16-18.

${ }^{27}$ Rechenberg 2010, 71-85.
} 
kvanttiteoriaan, erityisesti aineen rakenteeseen liittyvästä Zeemanin ilmiöstä eli spektriviivojen jakautumisesta magneettikentän vaikutuksesta. Hän oli myös osallistunut alan konferensseihin ja pitänyt niissä esitelmiä. ${ }^{28}$

Helmut Rechenberg (1937-2016), Heisenbergin kaikkein viimeisin tohtoriopiskelija, tunnustettu Heisenberg-auktoriteetti ja tuoreimman, kaksiosaisen Werner Heisenberg - Die Sprache der Atome -elämäkerran (2010) kirjoittaja on arvelut, ettei Sommerfeld tohtinut professorina antaa vielä varsin vakiintumattomaan atomin rakenteeseen liittyvää aihetta väitöskirjan tekijälle. Esimerkiksi saman yliopiston kokeellisen fysiikan esimies, professori Willy Wien käytti väitösten läpimenon kannalta merkittävää sananvaltaa ja suhtautui hyvin kriittisesti nuoremman polven kvanttiteoreetikkoihin. ${ }^{29}$

Heisenbergin Zeemanin ilmiöön kehittelemä malli aiheutti niin suunnattomia pulmia fyysikoille, ettei Sommerfeldillä ehkä ollut kanttia pysyä tähtioppilaansa takuumiehenä. Esimerkiksi David Cassidy, 1990-luvun Heisenberg-biografi, on arvellut Sommerfeldin tästä syystä ryhtyneen oppilaansa hienoiseen suitsemiseen ja pitäneen tämän klassisen fysiikan osaamisessa olevien aukkojen tilkitsemistä siihen oikeana lääkkeenä. ${ }^{30}$ Siksi Heisenberg sai aiheen hydrodynamiikan parista. Väitöstutkimuksen kohteena oli sinänsä hyvin vaativa, virtauksen turbulenssia koskeva matemaattinen mallintaminen.

Heinäkuun 23. päivänä 1923 pidetystä väitöstilaisuudesta - käytännössä pää- ja sivuaineiden professorien pitämästä suullisesta kuulustelusta (examen rigorosum) - oli vähällä tulla katastrofi. ${ }^{31}$ Heisenberg ei ollut erityisemmin ollut kiinnostunut kokeellisesta fysiikasta, ja hatara käsitys erilaisten mittavälineiden tai laitteiden toimintaperiaatteista koitui hänen kohtalokseen. ${ }^{32}$ Kuten edellä mainittu, tätä oppituolia piti hallussaan vuoden 1911 nobelisti Wilhelm (Willy) Wien. Hän aloitti suullisen kuulustelunsa spektrometriä koskevilla kysymyksillä, joihin väittelijä ei osannut vastata. Jatkokysymykset eivät onnistuneet sen paremmin: Heisenberg ei pystynyt selittämään mikroskoopin, kaukoputken eikä edes akun toimintaperiaatetta. Kaikkia näitä oli Wienin luennoilla kuitenkin käsitelty perusteellisesti, ja siksi professori ärsyyntyi. Hän esitti tutkinnon hylkäämistä. Sommerfeld puolusti tähtioppilastaan vetoamalla tämän korkeimman mahdollisen arvosanan saaneeseen kirjalliseen työhön. Heisenbergin tohtorintutkinto hyväksyttiin lopulta keskiarvolla cum laude. Se oli šokki opettajalle ja valtava pettymys doktorandille. ${ }^{33}$

Partiotoimintaa aktiivisesti harrastanut Werner Heisenberg haki huonosti sujuneen kuulustelun ja tohtoritutkinnon odotettua heikomman arvosanan aiheuttamaan nöyryytyksen tunteeseen etäisyyttä osallistumalla jo muutaman päivän päästä Saksan nuorisojärjestöjen liittopäiville (Bundesfest und Grenzfeuer der vereinigten deutschen Jugendbünde) Weissenstadtissa Fichtel-vuoriston kupeessa. Se, mitä maassamme ei ole aiemmin tiedetty

\footnotetext{
${ }^{28}$ Mt., 105-116; Cassidy 1992, 117-127.

${ }^{29}$ Rechenberg 2010, 120.

${ }^{30}$ Cassidy 1992, 127.

${ }^{31}$ Cassidyn 1992, 151 mukaan Münchenissä väittelijän saama arvosana perustui väitöskirjaan ja suulliseen kuulusteluun. Jälkimmäisessä oli mukana pääaineen ja molempien sivuaineiden opettaja. Kun fysiikka jakautui Ludwig-Maximilians-yliopistossa Wienin ja Sommerfeldin kesken, Heisenbergin kuulustelussa olivat mukana nämä molemmat sekä Oskar Perron (1880-1975) matematiikan ja Hugo von Seeliger (1849-1924) tähtitieteen edustajina.

${ }^{32}$ Rechenberg 2010, 136-139; Cassidy 1992, 151-153.

${ }^{33}$ Rechenberg 2010, 137-139, Cassidy 1992, 152-153; Tuominen 2017.
} 
eikä tutkittu on, että sieltä hän suuntasi matkansa suoraan oman vartionsa Gruppe Heisenbergin kanssa Berliinin ja Stettinin kautta kolmeksi viikoksi Suomeen. ${ }^{34}$

\section{Nuorisoliikkeet ja partioaate Heisenbergin kompasseina}

"Elämänarvoni juontuvat loppujen lopuksi paljolti niistä kulttuuriin ja erityisesti taiteeseen liittyvistä arvoista, joiden kanssa olin aikoinaan tekemisessä nuorisoliikkeen parissa", Heisenberg on todennut elämänsä loppupuolella 1960 -luvulla. ${ }^{35}$ Ensimmäisen maailmansodan jälkeen 1920-luvusta tuli maailmanlaajuisestikin nuorison ja nuoruutta ihannoivan kulttuurin vuosikymmen, sillä vasta aikuisuuden kynnykselle päässeet olivat menettäneet luottamuksensa aikansa eläneisiin konventioihin, vanhaan järjestykseen ja sen auktoriteetteihin. He kerääntyivät yhteen etsiäkseen uusia polkuja tai jotain, jonka avulla he voisivat suunnistaa ulos toivottomuudesta. ${ }^{36}$

Sota ja sen aiheuttamat kärsimykset antoivat nuorille ikään kuin oikeutuksen luoda itselleen oma mittapuu, jolla arvioida niin uutta kuin mennyttä. Kun aiemmat rakenteet ja elämisen muodot oli räjäytetty taivaan tuuliin, nuorten omista lähtökohdista nousevat teemat ja henkiset sisällöt murtautuivat esiin. Saksalainen nuorisoliike löysi esimerkiksi uusia tapoja musiikin harjoittamiseen, teatteriharrastukseen ja taidekäsityöhön. Nuoren sukupolven kouluissa opettajat näkivät vaivaa ja osoittivat uhrimieltä etsiessään uusia kasvatusnäkemyksiä, ja tieteessäkin keskityttiin aloille, joissa ei ainoastaan jatkettu vanhoilla urilla. Idealistinen, aatemaailmaltaan sosiaalidemokraatteihin kallellaan oleva Werner Heisenberg halusi hänkin jo nuorukaisena kantaa kortensa kekoon ja nostaa työväestön osaamistasoa. Hän veti vuosina 1920 ja 1921 työväenopistossa iltakoulukursseja niin astronomiasta kuin saksalaisesta oopperasta. ${ }^{37}$

Erityisesti kuitenkin uusi partioliike muodostui ensimmäisen maailmasodan jälkeisten kaoottisten vuosien aikana elämänalueeksi, josta nuori Heisenberg löysi mielekkään näkymän tulevaisuuteen - ja pitkäaikaiset ystävyyssuhteet. Aikuisten ja heidän arvojensa mukainen Wehrkeraftverein oli muutettu kevään 1919 tapahtumien jälkeen nuorbaijerilaisjärjestöksi (Jung-Bayern), ja aiemmista katukuvassa näkyneistä joukkueharjoituksista oli pitkälle luovuttu työväestön vastustaessa kaikkea militaristiseen toimintaan viittaavaa. Maxilimilians-lyseon WKV 18B -ryhmästä monet pojat olivat jääneet harrastuksessaan tyhjän päälle. He eivät halunneet ketään opettajaa tai aikuista vetämään toimintaansa, vaan tavoittelivat aitoa, nuorista itsestään kumpuavaa aatetta ja alkoivat siksi etsiä jotakuta vanhempaa lukiolaista ryhmänsä johtajaksi. Siksi muutama heistä kääntyi kahdeksasluokkalaisen gymnasiasti Heisenbergin puoleen ja pyysi tätä vetäjäkseen. ${ }^{38}$

\footnotetext{
${ }^{34}$ Lyhyessä artikkelissaan Kimmo Tuominen $(2017,21)$ mainitsee ilmeisesti Cassidyn biografiaan perustuen Heisenbergin Suomen-retken (ks. Cassidy 1992, 160), mutta kirjoittaa ehdottoman virheellisesti ja ilman väitettä tukevia lähdeviitteitä, että oppaina olisivat olleet saksaa puhuvat jääkärit.

${ }^{35}$ Kirjeessä 1963 ystävälleen Johannes Zielinskille (sit. Rechenberg 2010, 40): "Meine Wertvorstellung stammt schliesslich zu ainem nicht geringen Teil aus der Begegnung mit kulturellen, insbesondere künstlerische Werten aus der Zeit der Jugendbewegung."

${ }^{36}$ Cassidy 1992, 64-66.

${ }^{37}$ Rechenberg 2010, 40; Cassidy 1992, 71-72.

${ }^{38}$ Cassidy 1992, 66-67.
} 
Toverina hyvin pidetty, matemaattisen ja musikaalisen lahjakkuutensa takia arvostettu, vaellus-, telttailu-ja vuorikiipeilytaidoistaan tunnettu Heisenberg suostui ryhmän johtajaksi. Näin kesäkuussa 1919 syntyi lopulta seitsenhenkinen nuorempien koululaisten Gruppe Heisenberg, jota sen johtaja alkoi luotsata löytääkseen itselleen ja ryhmälleen mielekkyyden ja motivaation elämään sodanjälkeisessä Saksassa. ${ }^{39}$

Aluksi ryhmä toimi väljästi koulun vetämässä Jung-Bayern -liikkeessä, mutta irtaantui siitä vähitellen erilaisten sotilaallisempien ja lähinnä ulkoilmasuuntautuneiden seikkailijoiden välisten erimielisyyksien takia. Heisenberg ylipäätään vahvisti, enemmän kuin monet muut partion vetäjät, ryhmänsä itsenäisyyttä ja riippumattomuutta ja karttoi hierarkkisia muotoja tai auktoritatiivisia sääntöjä. "Werner ei ole mikään muodollisuuksien ystävä, siinä mielessä hänessä ei ole tavanomaisen partiojohtajan aineksia", yksi ryhmän jäsenistä, Heinrich Marwede, kirjoitti keväällä 1921 ja jatkoi: "Ulkonaisesti Werner on johtajamme, mutta todellisuudessa hän on vain joukon paras, 'primus inter pares', ja meistä jokainen on toisemme johtaja." Kaikki jäsenet olivat yhtä mieltä, ettei johtamistapa ollut koskaan diktatorinen. Heisenberg antoi virikkeitä ja piti huolta heistä, auttoi läksyissä, jos se oli tarpeen ja antoi neuvoja ilman että vaati tai määräsi. Gruppe Heisenbergissa arvostettiin alhaalta ylöspäin -johtamista, sitä että ryhmänjohtaja antoi vain suunnan ja että tämän persoonallisuus eikä muodollinen asema oli tehtävän ytimessä. Alkuperäisestä ryhmästä jo vuonna 1921 eronnut, Heisenbergia kaksi vuotta nuorempi jäsen Wilhelm Riffelmacher olikin ainoa, josta myöhemmin tuli Hitlerin vannoutunut kannattaja ja kansallissosialistisen puolueen jäsen. ${ }^{41}$

Heisenbergin ryhmä liittyi vasta myöhään ja pitkän puntaroinnin jälkeen 1922 "uuspartiolaisiin" eli Neudeutsche Pfadfinder -uudistusliikkeeseen, jonka joihinkin muotoihin, aatteisiin tai "historiallisromanttiseen" haaveiluun Heisenbergin oli vaikea yhtyä. Siitä huolimatta hän oli osallistunut toveriensa kanssa järjestön järjestämille useille valtakunnallisille partiopäiville. Uudistusliike oli saanut alkunsa Regensburgista 25-vuotiaan sotaveteraani Franz-Ludwig Habbelin johtamasta toiminnasta. Juuri Habbelin johdolla pidettiin elokuun alussa 1919 Baijerin Altmühltalin Schloss Prunnissa ensimmäinen suuri kokoontuminen, jossa uuspartiolaiset julistautuivat virallisesti nuorisoliikkeeksi. Heisenberg osallistui tähän 250 saksalaisen ja itävaltalaisen partiojohtajan tapahtumaan, ja siitä muodostui eräänlainen kulmakivi ja vedenjakaja hänen elämänkatsomukselleen. ${ }^{42}$

Werner Heisenberg oli kuunnellut Schloss Prunnin partiotapaamisessa eri puheita ja näkökantoja melko kriittisesti, koska löysi niistä vain osatotuuksia ja pieniä palasia uuden uskottavan maailmankatsomuksen sijaan. Hän kaipasi jonkinlaista kokoavaa ja stabilisoivaa, oikeasti tepsivää voimaa, jonka perustalle sodanjälkeisessä Saksassa voisi henkisen aatemaailmansa rakentaa. Yhtäkkiä, iltahämärässä soineen J.S. Bachin sooloviulu-Chaconnen ansiosta hän löysi etsimänsä keskitien, sisäisen harmonian ja lainalaisuudet, jotka hänen maailmassaan rakentuisivat tieteen, filosofian, musiikin ja uskonnon ikään kuin ihmisten mieltymyksistä vapaille periaatteille. ${ }^{43}$

\footnotetext{
${ }^{39}$ Becker 2019, 33-45; Cassidy 1992, 66-68.

${ }^{40}$ Rechenberg 2010, 58-59. "Werner ist kein Freund von offiziellen Sachen - er ist kein Stammesführer. Nach aussem ist Werner unser Führer, in Wirklichkeit ist er primus inter pares, und jeder ist sozusagen des anderen Führer."

${ }^{41}$ Mt., 58.

42 Rechenberg 2010, 45; Cassidy 1992, 68-71.

${ }^{43}$ Cassidy 1992, 76-77, Rechenberg 2010, 45-46.
} 
Kuva 2. Säveltäjä, professori Erkki Melartin vuonna 1925. Valokuva kirjoittajan yksityisarkistosta.

Heisenberg oli jo tuossa vaiheessa lähes konserttitason pianisti ja kamarimuusikko ja syvällisesti perehtynyt niin antiikin kuin myöhempien aikojen filosofien ajatteluun. Klassisten näytelmien esittäminen ja maailmankirjallisuuden ääneen lukeminen kuuluivat sekä hänen lapsuudenperheensä että partiotoveriryhmänsä elämäntapaan. Näiden kaikkien - tieteen, taiteen, filosofian ja teologian - ytimestä Heisenberg löysi sellaisia arvoja, joiden varaan hän pystyi rakentamaan oman tiensä. Cassidyn mukaan partiotovereistaan ja tästä omaksumastaan keskitien maailmanjärjestyksestä hän lopulta tunsi löytäneensä paikkansa maailmassa. ${ }^{44}$

Helmut Rechenberg on päätellyt intensiivisen omistautumisen partioryhmälle ja sen parissa hankitut ystävyssuhteet, vaellusretkien tuomat yhteisesti jaetut kokemukset, ajatustenvaihdon ja erilaisista näkemyksistä käydyt vapaat keskustelut sekä rajattoman luottamuksen toisiinsa olleen yhdistävinä tekijöinä ja antaneen Heisenbergin persoonaan lujuutta myöhempinä vuosina. Ne olivat eräänlainen kompassi orientoitumisessa sodanjälkeiseen aikaan. "Niin henkilökohtaisissa ratkaisuissaan kuin tieteessäkin hän etsi jatkuvasti sellaista keskitien päämäärää ja periaatetta, joka pitäisi kaiken koossa", tämä Heisenberg-asiantuntija toteaa. ${ }^{45}$ Partiotoiminta toi Heisenbergin myös Suomeen, jossa hän tutustui säveltäjä Erkki Melartiniin ja oli tämän kanssa kirjeenvaihdossa kymmenen vuotta aina Nobel-palkinnon saamiseensa asti.

\section{Gruppe Heisenbergin ensimmäinen suuri ulkomaanmatka 1923}

Tutkijanuran ja partiotoiminnan yhteensovittaminen ei ollut helppoa väitöstään valmistelevalle Heisenbergille. Hän oli osallistunut helluntaina toukokuun puolessa välissä Baijerin uuspartiolaisten liittopäiville Schloss Prunnissa, ja kesäpäiväntasauksen juhlaa oli vietetty metsässä nuotion ääressä laulaen, viulunsoittoa kuunnellen ja tarinoita kertoen. Kirjeessään 30.6.1923 ryhmänsä jäsenelle Wolfgang Rüdelille Heisenberg arveli pystyneensä siihen asti yhdistämään fysiikan ja partiotoiminnan melko hyvin, jopa niin, etteivät muut edes huomanneet, milloin hän teki töitä. "Kuitenkin kysymys kuuluu, kuinka kauan tällaista jaksaa. Uskon sinun laillasi, ettei näin pitkän päälle voi jatkua. Mutta siihen sitten liittyykin etenemis-

\footnotetext{
${ }^{44}$ Cassidy 1992, 77.

45 Rechenberg 2010, 61: "Im Persönlichen wie im Wissenschaftlichen suchte er stets nach dem Gesetz der 'Mitte', die alles zusammenhält."
} 
mahdollisuuden käsite. Fysiikan parissa katson kohdallani siihen mahdollisuuksia olevan, musiikin osalta se onkin jo epävarmempaa", hän jatkoi. ${ }^{46}$

Väitöskirjatyö tuntui välillä tuskastuttavalta. "Kaiket päivät vain fysiikkaa", hän kirjoitti (14.7.1923) Rüdelille, ”ja kun olin esimerkiksi yökävelyllä [partiotoveri] Rudi Hotzin kanssa, huomasin jälleen, miten sellainen elämä on täysin erilaista kuin mitä nyt joudun viettämään ja että olen etääntynyt mailien päähän siitä 'onnen tiestä', jota pitkin aiemmin pitkään kuljin. Mutta eipä auta. Kenelle sattuma suo onnen... Mutta entä jos ammatti rääkkää väkivalloin tästä ystävästä kaiken inhimillisen. Se on todella..., en tiedä mitä, itsensä hengiltä ottamiseen sitä on liian heikko." ${ }^{47}$

Osallistuminen elokuun 1923 alussa uuspartiolaisten yhteisille liittopäiville Weissenstadtissa ja sen jälkeen kesäretki Suomeen antoivat kuitenkin 21-vuotiaalle muutakin ajateltavaa. Helsinkiläisestä 1919 perustetusta Valon pojat -lippukunnasta oli nimittäin kymmenen partiolaisen ryhmä tulossa Weissenstadtiin ensimmäiselle Saksan-matkalleen, ja vastavuoroisesti müncheniläisille oli esitetty kutsu tulla Suomeen kolmeksi viikoksi. Jorma Pohjapalon mukaan Valon pojat oli elätellyt jo vuoden päivät toivetta päästä matkaan. Toiveen muuttumisesta todellisuudeksi "oli kiittäminen Erkki Melartinia, jonka henkilökohtainen kosketus saksalaisiin partiojohtajiin teki mahdolliseksi tämän ikimuistoisen retken". ${ }^{48}$ Melartinin arkisto sisältääkin kaksi kirjettä vuosilta 1920 ja 1925 Ludwig Voggenreiterilta, joka yhdessä Franz-Ludwig Habbelin kanssa oli Neupfadfinder-aatteen johtohahmoja ja tähän aatteeseen liittyvää kirjallisuutta kustantaneen Verlag Der Weisse Ritterin perustajia. Melartinilla oli siten suora kontakti aivan huipulle, ja kun Valon Poikien lippukunnan johtajana oli hänen sävellysopiskelijansa Onni Lampén ja jäsenenä hänen suojattinsa, konservatorion laulunopiskelija Thure Åberg, hän totta kai oli valmis auttamaan. ${ }^{49}$

Melartin oli säveltänyt jo vuonna 1911 partiopoikain marssin Var redo! (op. 61 nro 2) Nino Runebergin sanoihin, jotka suomeksi oli kääntänyt Jalmari Finne. On mahdollista, että hänet tästä syystä oli nimitetty Suomessa hyvin varhaisessa vaiheessa partiojärjestön kunniajäseneksi. Vuonna 1920 Melartin kutsuttiin myös Valon Poikien veljesritariston kunniajäseneksi. ${ }^{50}$

\footnotetext{
46 "Dass es auf die Dauer doch nicht geht, glaub ich auch. Aber da setzt gerade der Begriff der Steigerungsmöglichkeiten ein. Die Physik muss ich für mich dazu rechnen; bei der Musik wird's schon zweifelhaft." Sit. Becker 2019, 235.

${ }^{47}$ Mt., 235: "Den ganzen Tag nichts als Physik aber hab ich z.B. heut einen Nachtspaziergang mit Rudi Hotz gemacht, da merk ich wieder, dass das Leben so ganz anders ist, als wie ich mich jetzt herumtreiben muss und dass ich vom 'Weg des Glücks', auf dem ich früher lange gegangen bin, mich meilenweit entfernt hab. Aber was hilfts? 'Wem der grosse Wurf gelungen...'". Viimeinen lause on sitaatti Schillerin runosta An die Freude.

48 Pohjanpalo 1974, 140.

${ }^{49}$ Linnavuori 2017 mukaan partioharrastus rantautui maahamme Ruotsin kautta Isosta-Britanniasta. Jo vuonna 1910 Suomeen perustettiin ensimmäiset partiopoikajärjestöt, mutta Venäjän hallitus näki partioharrastuksen kannustavan itsenäisyyttä tukevaan toimintaan ja päätti kieltää sen vuonna 1911. Toiminta sallittiin jälleen 1917. Lampénin (myöh. Karte) ja Åbergin (myöh. Ara) lisäksi matkalla olivat Jorma Pohjanpalo, Erkki Vikman, Gunnar Svahnström, Seppo Alanne, Armas Häkkänen, Lauri Laakso, Mauno Inkinen ja Tauno Kilpinen (Becker 2019, 253. Huom! Becker olettaa Melartinin ja Habbelin sopineen Valon Poikien matkasta, mutta Melartinarkistosta ei tällaista kirjeenvaihtoa löydy).

${ }^{50}$ Nimimerkki Reportteeraaja 1920.
} 
Kuva 3. Erkki Melartinin 1909 säveltämän partiomarssin kansilehti. Valokuva Partiomuseon kokoelmista.

Heinäkuun puolessa välissä 1923 partiojohtaja-Heisenberg oli vielä epävarma siitä, onnistuuko Suomen-retki ollenkaan. "Mihin matka sitten sattuukin suuntautumaan, on minulle melko samantekevää, kunhan en joudu kuulemaan enkä näkemään mitään siitä, minkä parissa nyt kaiket päivät puuhaan”, hän kirjoitti 14.7.1923 Wolfgang Rüdelille. Samassa kirjeessä hän kertoi "kunnianarvoisan tutkintonsa" olevan tulossa parin seuraavan viikon aikana. "Siitä lähtien kun olen tiennyt, että tutkinnon ajankohta riippuu vain siitä, kuinka suuren taskurahan sujauttaa herra vahtimestarin käteen, minua puistattaa inhosta", hän vielä kuvasi yliopiston toimintakulttuuria. ${ }^{51}$

Epäonnistuneen väitöstilaisuutensa takia Heisenbergilla ei ollut syytä juhlia Münchenissä tutkintoaan. Göttingenin yliopiston fysiikan professori Max Born oli luvannut hänelle syksystä 1923 alkaen assistentuurin osastollaan ja muisteli myöhemmin, miten vastaleivottu tohtori oli ilmestynyt hänen luokseen paljon ennen sovittua ajankohtaa - nimittäin jo väitöstä seuranneena aamuna - ja kysynyt, vieläkö häntä haluttiin Göttingeniin. Born oli kuitenkin havainnut tämän nuoren miehen lahjakkuuden ja kirjoittanut esimerkiksi puoli vuotta aiemmin Sommerfeldille: "Pidän Heisenbergista erittäin paljon, ja häntä arvostetaan täällä. Hän on ennenkuulumattoman lahjakas, mutta erityisen ilahduttava on hänen ystävällinen, vaatimaton olemuksensa, hyväntuulisuutensa sekä hänen intonsa ja innostuksensa." Oli selvää, että sopimus uuden assistentin kanssa piti. ${ }^{52}$

Viiden päivän päästä tästä tapaamisesta Heisenberg oli jo matkalla ryhmänsä kanssa Weissenstadtiin partiopäiville. Siellä hän tapasi Onni Lampénin johtaman suomalaisryhmän, jonka kotiinpaluun yhteydessä nämä saksalaisista "reippaimmat ja uhkarohkeimmat" lähtivät partiohengen mukaisesti seikkailemaan kolmeksi viikoksi Suomeen käytännössä ilman rahaa edes laivamatkaan. ${ }^{53}$

Stettinissä kaksi saksalaista laivayhtiötä kieltäytyi ottamasta saksalaisia partiolaisia matkalle ilmaiseksi, mutta päättäväinen ryhmänjohtaja Heisenberg kääntyi suomalaisen Ariadnen puoleen. Varustamon saksankielinen henkilökunta ei myöskään ojentanut auttavaa kättä, mutta Heisenberg pääsi puhumaan laivan kapteenin kanssa. Tämäkään ei voinut ottaa ryh-

\footnotetext{
${ }^{51}$ Becker 2019, 232-235.

52 Rechenberg 143-144.

${ }^{53}$ Becker 2019, 237, 261.
} 
mää mukaan tarjotulla yhdeksällä dollarilla, kun jo yhden henkilön Itämeren-ylitys laivalla maksoi 70 dollaria. Nyt kuitenkin Ariadnen kaikki matkustajat kiinnostuivat tästä periksi antamattomasta neuvottelusta, ja lopulta viipurilainen turkiskauppias Salomon Koschak lupasi antaa 15 dollaria lisää matkakassaan. Näin lähtö lopulta onnistui. Heisenbergin partiolaisia pidettiin koko matkan suosikkeina niin, että suomalaiset matkustajat tarjosivat heille jatkuvasti kahvia ja kakkua. Heisenberg ja Thure Åberg myös esiintyivät laivan musiikkisalongissa, edellinen soitti Beethovenin sonaatteja ja jälkimmäinen lauloi suomalaisia ja saksalaisia liedejä.

Helsinkiin saavuttiin elokuun 10. päivänä upeassa kesäsäässä. Saksalaiset majoitettiin partiolaisten tai heidän suojelijoidensa perheisiin. Kolmen päivän päästä he matkustivat junalla Viipuriin Onni Lampénin ja saksaa puhuvan Hannu Inkisen johdolla. Viipurissa Melartinin varakas ystäväpariskunta Viktor ja Elin Sellgren kestitsi joukkoa osoittaen Heisenbergin sanoin "suorastaan ruhtinaallista vieraanvaraisuutta". Viipurista matka jatkui Imatran koskia ihailemaan ja Vuoksenniskaan sekä Savonlinnaan, jossa heillä oli virallinen partiolaisten vastaanotto. Heisenbergia ihmetytti Savonlinnassa ja muutenkin Suomessa se, että partiolaisista suurempi osa oli tyttöjä kuin poikia. Saksassa tilanne oli päinvastainen. Illanvietto sujui aivan liikuttavan vieraanvaraisuuden ja ystävällisyyden merkeissä. Sen lopuksi opeteltiin tanssimaan suomalaisia kansantansseja, joita Heisenberg tosin piti hyvin primitiivisinä. ${ }^{54}$

Varsinaisena kokokohtana Heisenberg piti neljän päivän oleskelua Punkaharjulla, jossa "Teknillisen korkeakoulun rehtori (Alexander Hjelmman), eräs matematiikan professori (oletettavasti Hjalmar Mellin) ja yksi viipurilainen lääkäri” majoittivat heitä kesähuviloillaan. "Nämä aivan uskomattoman vieraanvaraiset suomalaiset kohtelivat meitä kuin perheenjäseniä, ja saimme tehdä mitä huvitti: soudella, metsästää [sorsia], kalastaa, pelata tennistä ja tehdä retkiä; illalla musisoitiin ja laulettiin perhepiirissä - lyhyesti sanottuna elimme kuin satumaassa", Heisenberg kuvasi kokemuksiaan partiojohtaja Franz-Ludwig Habbelille kirjeessä 24.9.1923. ${ }^{55}$

Suomen-retki jatkui Sortavalaan ja sieltä rajavartiointialuksella Laatokan melkoisessa myrskyssä Valamoon. Kaikkien merisairaiden ja pahoinvoivien joukossa kuitenkin Heisenberg ja hänen toverinsa Emil Kallhardt pelasivat kajuutassa kylmän rauhallisesti shakkia. "Ilmeenkään värähtämättä ja meidän voinnistamme yhtään piittaamatta Werner voitti. Hänhän voitti aina", muisteli Kurt Pflügel vielä 40 vuotta myöhemmin. ${ }^{56}$ Valamossa arkaainen kreikkalaisvenäläinen tunnelma, ortodoksinen jumalanpalvelus ja venäläistyyppinen ruoka pikemminkin ihmetyttivät kuin ihastuttivat seuruetta. Kurt Pflügelin mukaan munkit katsoivat heitä vääräuskoisia hieman pahalla. Ja kun jumalanpalveluksessa heiluteltiin suuria suitsukeastioita, partiolaisia lähimpänä olevasta astiasta irtosikin kädensijan ketju, ja hehkuvat kekäleet lensivät ympäriinsä alttarin portaita. Kaikki katsoivat tapahtunutta aivan ällistyneinä, kunnes yksi heistä kuiskasi: "Se johtui meidän epäuskostamme."57

\footnotetext{
${ }^{54}$ Heisenberg kirjeessään Habbelille kirjeessä 24.9.1923. Kopio kirjoittajan hallussa, sit. myös Becker 2019, 258-261.

55 "Bei der unglaublichen Gastfreundlichkeit der Finnen fast als Familienangehörige, konnten wir tun, was uns freute: Rudern, Jagen, Fischen, Tennis spielen, Ausflüge machen; abends wurde im häuslichen Kreise musiziert, gesungen - kurz, wir lebten wie in einem Märchenlande." Em. kirje, sit. myös Becker 2019. Matkalle osallistuivat matkanjohtaja-Heisenbergin lisäksi Walter Weigmann, Hans Schmeer, Kurt Pflügel, Robert Honsell, Emil Kallhardt, Rudolf Hotz, Otto Heimeran, Artur Mackel ja Otto von Bechtolsheim.

56 "Ohne eine Miene zu verziehen und ohne sich um unseren verstörten Zustand zu kümmern, siegte Werner. Denn Werner gewann immer." Kopio kirjeestä kirjoittajan hallussa, sit. myös Becker 2019, 262.

57 "Das war unser Unglaube." Kopio kirjeestä kirjoittajan hallussa, sit. myös Becker 2019, 262-263.
} 
Kuva 4. Werner Heisenberg Suomessa, oletettavasti Erkki Melartinin kodin puutarhassa elokuussa 1923. Valokuva Jochen Heisenbergin / Heinrich Beckerin yksityisarkistosta.

Helsinkiin ryhmä palasi 26. elokuuta. Silloin he tutustuivat Erkki Melartiniin, jota Werner Heisenberg piti mielenkiintoisimpana heidän kaikista Suomessa kohtaamistaan ihmisistä. Suomalaisen partioliikkeen suojelijana tämä ei osallistunut varsinaiseen toimintaan, mutta tunsi henkilökohtaisesti jokaisen jäsenen ja puuttui hienovaraisesti taustalta asioihin, jos ne eivät sujuneet. "Erkin saattoi vaivatta lukea nuorisoliikkeen jäseneksi, vaikka hän täyttääkin ensi vuonna 50”, Heisenberg kirjoitti edellä mainitussa syyskuun kirjeessä Habbelille. Melartin oli ollut hyvin ystävällinen saksalaispojille heti alusta pitäen, jo kohta tehtiin sinunkaupat ja hyvästijätön yhteydessä

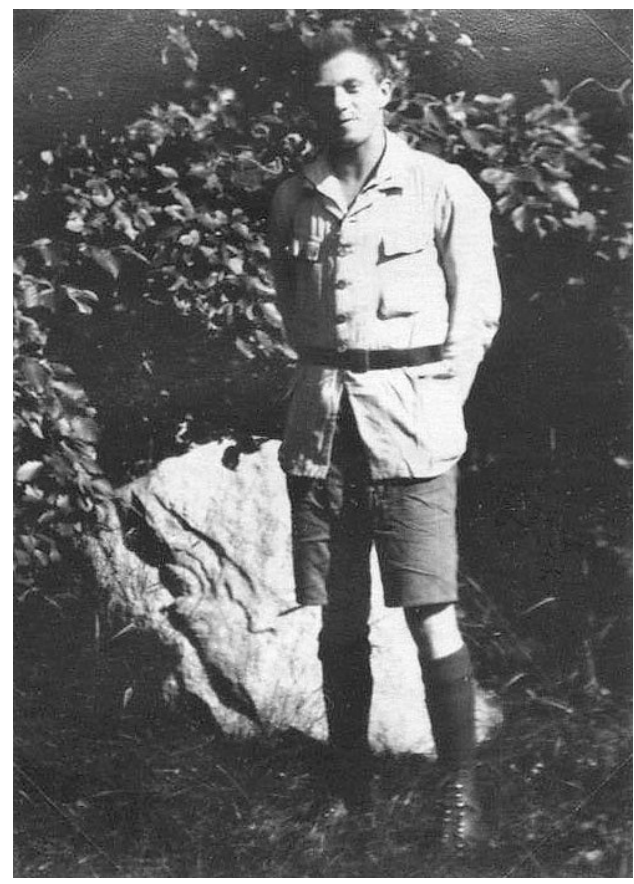
huomattiin, kuinka vaikeaa tämän oli jättää heidät. "Ylipäätään kaikki suomalaiset ovat hyvin tunteellisia, ja Erkki M:n kohdalla voi olla iloinen, että tätä sentimentaalisuutta verhoaa melkoinen temperamentti", Heisenberg huomautti kirjeessään 24.9.1923. ${ }^{58}$

"Päivät Erkin luona Boxbackassa olivat ihanimmat ja tunnelmaltaan ehyimmät Suomen-matkallamme", Kurt Pflügel kuvaili muistelmissaan. "Emme olleet vain vaellusretkellä olevia vaihto-oppilaita, joita hyvin toimiva ulkomainen järjestö tuki, vaan ikään kuin ensimmäinen sodanjälkeinen saksalaisnuorten kärkiryhmä. Tulimme Saksan suuresta päivänpoliittisesta sekasorrosta ja löysimme nuo ihmiset, jotka aidosti pyrkivät ymmärtämään meitä ja joiden kanssa heti löytyi samanlaisen elämänkatsomuksen harmonia. Musiikki-illat Wernerin ja Erkin johdolla olivat yhdessäolon kohokohtia", hän jatkoi. ${ }^{59}$

Myös Melartin teki partiolaisten vierailusta taskukalenteriinsa merkintöjä. Hän oli juuri palannut Tanskan-matkaltaan ja tapasi partiolaiset puolilta päivin. Seuraavana päivänä hän oli heidän kanssaan kaupungilla miltei koko päivän, johon sisältyi retki Korkeasaareen. "Ovat hyvin mukavia", Melartin kirjoitti muistiin. Seuraavana päivänä vuorossa oli Ateneum ja vierailu Melartinin kodissa Pukinmäellä. "Heillä on fenomenaalinen ruokahalu”, Melartin

\footnotetext{
58 "Es sind übrigens alle Finnen sehr sentimental u. bei Erkki M. ist man froh, dass diese Sentimentalität durch ein ungeheures Temperament überwuchert ist." Heisenberg Habbelille 24.9.1923. Kopio kirjeestä kirjoittajan hallussa., sit. myös Becker 2019, 260.

59 "Die Tage in Boxbaka [!] mit Erki [!] Melartin waren die schönsten und geschlossensten Tage der Finnland-fahrt. Wir waren nicht wandernde Austauschstudenten, unterstützt von einer wohlfuntionierenden Auslandsorganisation. Wir waren die erste Stossgruppe der deutschen Jugend nach dem Kriege. Wir kamen in Tagen grösser politischer Wirrnisse in Deutschland und fanden jene Menschen, die uns zu verstehen versuchten und mit denen schnell die Harmonie der gleichen Lebensführung gefunden war. Die Musikabende, geführt von Werner und Erki, waren dabei die Höhepunkt." Kopio kirjeestä kirjoittajan hallussa, sit. myös Becker 2019, 263.
} 


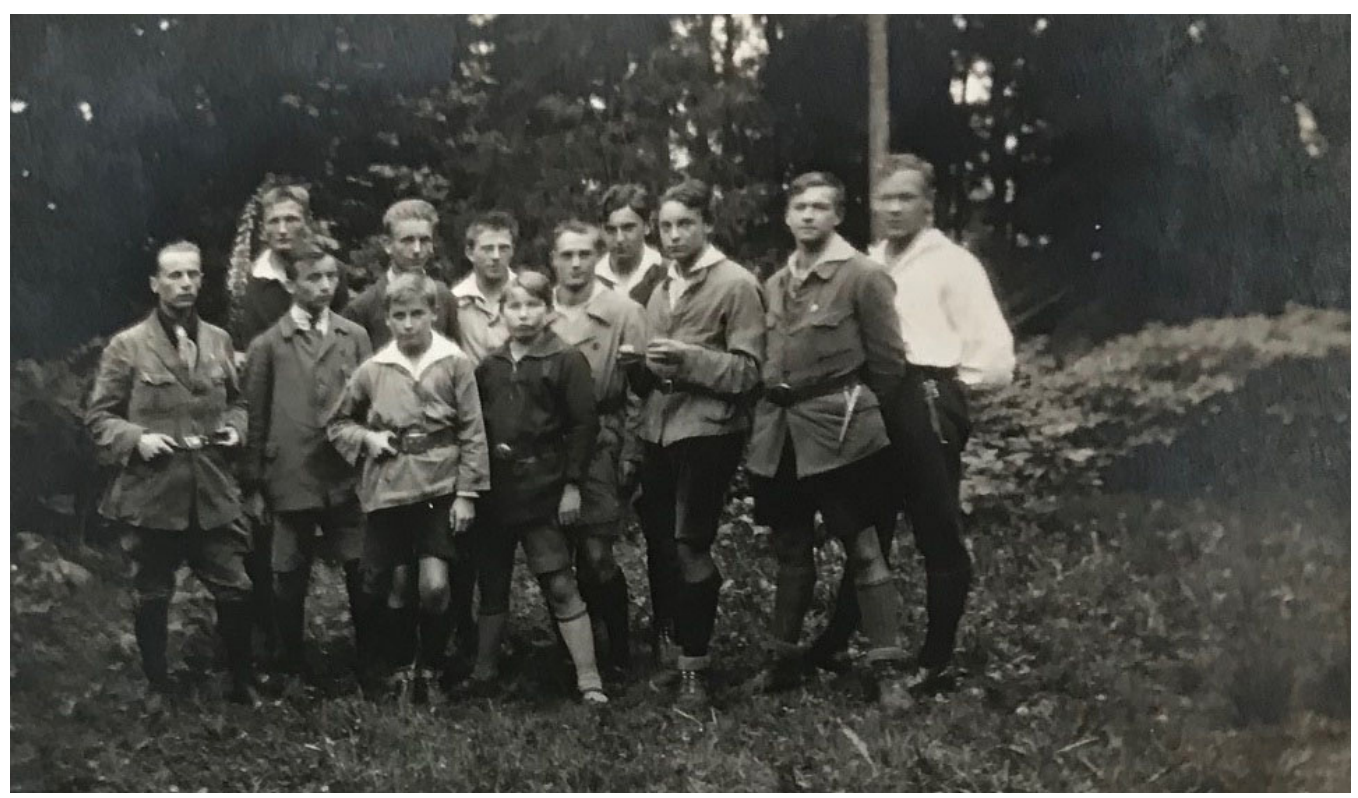

Kuva 5. Saksalaiset partiolaiset Erkki Melartinin Pukinmäen huvilan pihalla. Keskellä takana Heisenberg, vasemmalla Valon poikien johtaja Onni Lampén ja oikealla sen yksi jäsen, Thure Åberg (Ture Ara). Valokuva Kansalliskirjasto.

merkitsi kalenteriinsa (28.8.1923). Saksalaisille olikin pieni ihme se, että Suomessa oli tarjolla elintarvikkeita, joista heillä sodan jälkeisessä pula-ajan Saksassa ei ollut juuri voitu unelmoida: kunnon maitoa, munia, voita, lihaa, marjamehua, pullaa. Esimerkiksi Kurt Pflügel kertoi kotiväelle, kuinka heidät Viipurissa oli heti asemalta noutanut joku saksalainen rouva kotiinsa kahville, sitten eräs herra oli vienyt hotelliin, jossa pöydät notkuivat kaikesta sellaisesta hyvästä syötävästä, mitä olemassa ylipäätään oli ja josta heidät nouti huvilalleen ja heti ruokailemaan taas uusi isäntä. ${ }^{60}$ Suomalaiset partiolaiset puolestaan olivat Saksan-matkallaan olleet kauhistuneita sikäläisen ruuan heikosta laadusta. ${ }^{61}$

Walter Weigmann kirjoitti vuotta myöhemmin Melartinille, kuinka merkityksellinen tapahtuma vierailu tämän kodissa oli ollut. "Muistan vielä erittäin hyvin kuinka onnellisia olimme, kun saimme käyttää runsasta kirjastoasi”, hän kuvaili ja jatkoi: "Minä otin käsiini sieltä Hölderlinsin runot. Meillä kaikilla oli pohjaton suuruuden ja kauneuden nälkä, ja kun siellä myös musisoitiin, olimme kuin taivaassa." 62

\footnotetext{
${ }^{60}$ Kirjeessä 16.8.1923, sit. Becker 2019, 269.

${ }^{61}$ Mt., 255-256, 258-279.

${ }^{62}$ Kirjeessä 18.8.1924:"Aber ich erinnere mich sehr gut, wie glücklich wir waren als wir Deine reiche Bibliothek benutzen durften. Ich hatte als einziger Hölderlins Gedichte dabei und so hatten wir alle einen unendl. Hunger nach Grossem u. Schönen. Und als erst noch musiziert wurde da war es für uns ein gleichsam der Himmel." Hans Schmeer muisteli kirjeessään Melartinille (20.10.1924), että Heisenberg ja Melartin soittivat tuolloin nelikätisesti Bruckeneria.
} 


\section{Heisenberg ja Melartin}

Saksalaisten partiopoikien tuttavuus Erkki Melartinin kanssa oli lyhytaikainen, mutta ilmeisesti hyvin intensiivinen. Melartin ylipäätään oli ihmisenä, opettajana ja johtajana poikkeuksellinen. Sekä hänen omana elinaikanaan että myöhemminkin hänen persoonastaan ja suhtautumisestaan kanssaihmisiin kirjoitettiin yksinomaan kiittävästi. Esimerkiksi Rolf Nevanlinna kuvaa muistelmissaan Melartinia "hienosti sivistyneeksi mieheksi, joka harrasti taiteilija-ammattinsa ohella muitakin kulttuurin aloja ja joka vieläpä tunsi kiinnostusta korkeampaa matematiikkaa kohtaan, mahdollisesti eränlaisena intellektuaalina salaoppina." 63

Melartinin elämänasenteeseen kuului "nähdä hyvää kaikissa ja kaikessa, suuri pienessä ja täydellinen epätäydellisessä”, ja hänen henkevyydestään ja monitahoisesta sivistyneisyydestään ylipäätään oltiin niin Suomessa kuin kansainvälisissä yhteyksissä hyvin yksimielisesti vaikuttuneita. ${ }^{64}$ Saksalaiset nuoret kokivat todennäköisesti hänet samoin kuin eräs Melartinin oppilas, joka kirjoitti muistosanoissa opettajastaan seuraavasti:

Kun Erkeki Melartin tuli silloisen musiikkkiopiston johtoon, bän oli nuori, loistavasilmäinen, liekehtivää elämää täynnä. Hän valloitti heti oppilaat ystävällisyydellään, joka poisti heistä pelon ja sai heidät yrittämään parbaansa. Vaikkea vuodet lisääntyivät ja värit vaalenivat, säilyi bänessä sama behkuva henki. Hän uskoi kaikista byvää ja boukutteli siten esiin jokaisen parhaimmat ominaisundet. ${ }^{65}$

Yhtenä osoituksena suuresta arvostuksesta ja varmasti ihanteellisesta aatteellisesta hengenheimolaisuudesta Melartinin ja Heisenbergin välillä voidaan pitää sitä, että Heisenberg matkusti varta vasten myöhemmin marraskuussa Göttingenistä Berliiniin osallistuakseen Melartinin 9.11.1923 Beethoven-salissa johtamaan Berliinin filharmonikoiden konserttiin. Ohjelma koostui yksinomaan hänen omista sävellyksistään. Heisenberg kirjoitti äidilleen Göttingenistä 7.11.1923: "Huomenna haluan matkustaa Berliiniin saadakseni pari päivää muutakin ajateltavaa kuin fysiikka ja myös kuullakseni Erkki Melartinin konsertin. Vietän siis Berliinissä nuo päivät maanantaihin asti." ${ }^{\prime 66}$

Säveltäjä kirjoitti Kurt Pflügelille konserttipäivän iltana kirjeessä: 'Kaikki sujui loistavasti, ja huolimatta rauhattomista ajoista sali oli täynnä ja ihastus yllättävän suuri. Mutta niinpä myös filharmonikot soittivat aivan loistavasti. Kun saavuin paikalle konserttiin, niin taiteilijalämpiöön ilmestyivät Werner Heisenberg ja Werner Marwede ja yksi kolmaskin kunnon veikko. Voit varmaan kuvitella, miten iloinen olin nähdessäni jälleen oman Wernerimme!'67 Konsertin jälkeen berliiniläisnuoriso ja joukko partiolaisia oli kokoontunut salin ulkopuo-

\footnotetext{
${ }^{63}$ Nevanlinna 1976, 89.

${ }^{64}$ Ranta-Meyer 2008, 59-74.

${ }^{65}$ Mt., 5. Dagmar Klemetti, joka opiskeli Melartinin johtamassa Helsingin Musiikkiopistossa, nykyisessä Sibelius-Akatemiassa vuosina 1908-1913, kirjoitti muistosanat 21.2.1937 Helsingin Uutisiin.

${ }^{66}$ Sit. Rechenberg 2010, 191: "Morgen möchte ich, um für ein paar Tage an etwas anderes als Physik zu denken, nach Berlin zu fahren, auch um das Konzert der Erkki Melartin anzuhören. Also bring ich die Tage bis Montag früh in Berlin zu."

${ }^{67}$ Kirjeessä 9.11.1923: "Lieber Kurt, heute nur ein paar kurze Zeilen nach dem Konzert. Es ging alles ganz glänzend gut und trots die unrugigen zeiten war der Saal voll und die Begeisterung unwartet hoch. Aber so haben auch die Philharmoniker glänzend gespielt. Als ich ins Konzert kam so trat in Künstlerzimmer. Werner Heisenberg und Werner Marwede ei dritter guter Junge. Du kannst dir denken wie froh ich wurde unseren Werner wiedezusehen!" Kopio kirjeestä kirjoittajan hallussa, sit. myös Becker 2019, 281.
} 
lella laulamaan Suomen kaartin paluumarssia. Taskukalenteriinsa Melartin kirjoitti (9.11.): "Min konsert med filharmonikerna lyckades storartat. Mycket folk och ovationer. -- [S] couterna sjöngo på finska Oi kallis kotimaa." Sunnuntaina berliiniläiset partiolaiset järjestivät juhlan Melartinin kunniaksi. Siitä juhlinnan kohde kirjoitti (11.11.): "Scouternas fest för mig på aftonen hos ministeriet vid Brandenburgtor. Storartat." Voidaan hyvin olettaa, että tässäkin juhlassa Heisenberg oli mukana, koska oli halunnut jäädä Berliiniin nimenomaan maanantaihin asti.

Toverillinen kirjeenvaihto Heisenbergin ja Melartinin välillä jatkui 1930-luvun alkupuolelle asti. Osa Heisenbergin tervehdyksistä on ollut postikortteja erilaisilta partio-, vaellus- ja lasketteluretkiltä. Niistä käy kuitenkin ilmi, että Suomen-matka oli hyvin paljon ystävysten mielessä ja että toista matkaa tänne suunniteltiin jo seuraavaksi kesäksi, vaikkei se sitten toteutunutkaan. ${ }^{68}$ Myös Melartin suunnitteli käyntiä Müncheniin alkuvuodesta, mutta siihen hänellä ei sittenkään ollut taloudellisia mahdollisuuksia. ${ }^{69}$

Kesällä 1924 dosentuurin Göttingenin yliopistossa saanut Werner Heisenberg oli vieraillut aiemmin Kööpenhaminassa Niels Bohrin luona ja sittemmin syyskuusta 1924 kevääseen 1925 työskenteli assistenttina tämän instituutissa Blegdamsvej 5:ssa. Tapaamismahdollisuuksia Melartinin kanssa olisi voinut olla paljonkin, sillä tämä vietti lähes kaikki lomansa tanskalaisten ystäviensä luona Kööpenhaminassa. Kirjeenvaihdossa puhuttiinkin usein mahdollisista jälleennäkemisistä Tanskassa, Münchenissä tai Helsingissä ja harmiteltiin aikataulujen ristiin menemistä, Heisenberg kun puolestaan halusi viettää lomansa kotonaan Münchenissä. ${ }^{70}$ Ylipäätään poissaolo kotimaasta tuntui Heisenbergista vaikeammalta kuin mitä hän oli osannut odottaa, ja hän paljasti Melartinille:

Minun pitää pakottaa itseäni olemaan ajattelematta sitä, jotten saa koti-ikävää. Kaikki tämä työ monien vieraiden kielten [englanti, tanska] opiskelun ja fysiikan parissa tekee sen, ettei aika täällä tunnu ollenkaan helpolta; se on varmaan rasittavin ja vaikein tähänastisista lukukausista. Monessa suhteessa olen kuitenkin vielä nuori poika; siinä suhteessa tämä aika, jos kaikki menee hyvin, vie minua eteenpäin myös inhimillisessä mielessä; tietty taistelutahto ja vahvuus ovat myös tarpeen; ruumiillisesti se on toki partiolaiselle helppoa kuin leikki, muissa suhteissa ilkeän vaikeaa. ${ }^{71}$

Useissa kirjeissä Heisenberg kuitenkin mainitsi, miten hänellä ammatillisesti sujui hyvin ja että hän on ollut onnekkaampi kuin ansaitseekaan. Mutta ammatti sinänsä ei aina tuntunut kovin tyydyttävältä. Hän koki, että työ jota hän joutuisi koko elämänsä tekemään, oli hyvin

\footnotetext{
${ }^{68}$ Esim. Heisenbergin lähettämä kortti 28.4.1924 ja kirje 19.6.1924 Melartinille.

${ }^{69}$ Melartin kirjeessä 15.12.1923 Pflügelille.

${ }^{70}$ Esim. Göttingenissä päivätty kirje 7.9.1924. Hans Schmeerin kirjeenvaihtosta Melartinin kanssa ilmenee, että myös muut Gruppe Heisenbergin jäsenet pyrkivät järjestämään tapaamisia hänen kanssaan eri puolilla Saksaa.

${ }^{71}$ Heisenberg 16.11.1924 Melartinille: "Überhaupt fällt mir's viel schwerer als ich gedacht hab, von Deutschland weg zu sein. Ich muss mich zwingen, nicht daran zu denken, um nicht Heimweh zu bekommen. Dies alles zusammen, die viele Arbeit für die Sprachen u. die Physik, amcht, dass mir die Zeit hier nicht leicht fällt; es ist sicher für mich das anstrengendeste u. schwierigste Semester bis jetzt. Zu mancher Berichung bin ich aber noch ein kleiner Junge, und deshalb wird dieser Zeit mich, wenn alles gut geht, sicher weiterbringen auch in menschlichen Berichung; eine gewisse Kampffähigkeit u. Stärke ist eben auch nötig; in körperliche Berichung fällt sie einem Pfadfinder immer spielend leicht, in anderen Berichungen oft gemein schwer."
} 
vähän yhteydessä todelliseen elämään. Sen sijaan ihanteelliseen nuorisoliikkeeseen kuuluneiden tovereiden kanssa tehdyt vaellukset ja retket luontoon tuntuivat aina paljon tärkeämmiltä kuin mitä hän Göttingenin tai Kööpenhaminan yksinäisyydessä teki. "Varmasti hymähdät paljolle sille, mitä esimerkiksi Weissen Ritter-partiolehdessä kirjoitetaan, ja syystäkin, mutta ne perusajatukset ovat muodostuneet meille jo eräänlaiseksi elämän ehdoksi”, hän kirjoitti Melartinille. ${ }^{72}$

Cassidyn mukaan Heisenbergin ja hänen vuotta vanhemman veljensä Erwinin välit olivat silmiinpistävän vähäiset. Erwin ei tule esiin millään tavalla nuoremman veljen virallisissa muistelmissa, eivätkä partiotoverit muistaneet koskaan tavanneensa häntä tai että hänen nimensä olisi mainittu keskusteluissa. Syinä tähän oli Cassidyn arvion mukaan veljesten isän tietoinen, keskinäistä kilpailua edistänyt kasvatustapa ja voimakasta sosiaalista nousua hamuava kunnianhimo. ${ }^{73}$ Erwin irtautui perheestä melko varhain, sillä hän saavutti vuonna 1917 asevelvollisuusiän, osallistui sotaan ja suoritti niin sanotun hätäylioppilastutkinnon (Notabitur), jonka jälkeen hän aloitti kemianopinnot Berliinissä. ${ }^{74}$ Hän ei toisin sanoen ollut läsnä veljensä tärkeinä nuoruusvuosina. Myöhemmin Erwin liittyi antroposofiseen liikkeeseen, mikä Cassidyn mukaan erotti veljeksiä entisestäänkin ja viilensi toisen maailmansodan jälkeen heidän välejään. Kuitenkin kirjeestä Erkki Melartinille 7.9.1924 käy ilmi, että Werner Heisenberg on Suomen-matkallaan kertonut myös veljestään, ja nyt vuotta myöhemmin hän pyysi Melartinilta pientä palvelusta.

Veljeni on, kuten muistat, kemisti ja hänellä olisi halu mennä töihin ulkomaille, mahdollisesti Suomeen. Hän haluaisi kovin mielellään jonkin osoitteen, josta hakea paikkaa. Hän on tällä hetkellä töissä Agfalla, jolla ei kuitenkaan ole Suomeen mitään yhteyksiä. En tietenkään tarkoita, että sinun pitäisi ponnistella asian suhteen, mutta kun ajattelin sinun tuntevan uskomattoman paljon ihmisiä, niin ehkäpä tunnet myös kemistejä. ${ }^{75}$

Tiedossa ei ole, millaisia kontakteja Melartin Erwin Heisenbergille löysi, sillä kirjeet tulevalle nobelistille eivät ole säilyneet. ${ }^{76}$ On kuitenkin hyvin todennäköistä, että Melartin yritti auttaa, sillä hän tunsi laajasti ainakin helsinkiläistä ja viipurilaista sivistyneistöä eikä yleensä jättänyt asioita sikseen. Ehkä veljesten välit eivät olleetkaan niin huonot kuin mitä Cassidy on olettanut. Werner Heisenbergin Melartinille ja partiotovereilleen lähettämien kirjeiden perusteella työ kvanttiteorian parissa vain vei totaalisesti hänen aikansa, ja kun ei asuttu lähekkäin, yhteydenpito luonnostaan jäi vähemmälle. Esimerkiksi 2.4.1925 Heisenberg kertoi kirjeessään partiotoveri Wolfgang Rüdelille olevansa liian väsynyt pystyäkseen kirjoittamaan oikeaa kirjettä, jota varten ei olisi sitä paitsi mitään kerrottavaakaan, kun päivät täyttyvät aamuyhdeksästä kello 12:sta yöllä vain fysiikasta. Myös tytär Anna Maria Hirsch-Heisenberg on arvellut, että kilpailun ohella veljekset olivat keskenään hyviä tovereita: he musisoivat

\footnotetext{
${ }^{72}$ Kirjeessä 7.9.1924: "Du wirst ja sicher über manches, was etwa in Weissen Ritten steht, lächeln u. mit Recht; aber die Grundgedanken sind für uns schon fast eine Art Bedingung für das Leben".

${ }^{73}$ Cassidy 1992, 14-15.

${ }^{74}$ Rechenberg 2010, 37; Cassidy 1992,15.

75 "Mein Bruder ist wie Du dich viell. erinnerst, Chemiker u. hätte Lust in Ausl. u. ev. nach Finnland zu gehen. Nun möcht er gern irgendeine Adresse wissen, wo er antragen kann. Er ist bis jetzt bei der Agfa angestellt, die hat aber in Finnland keine Verbindung. Ich meine natürlich nicht, dass Du dich irgendwie anstrengen sollst, sondern ich dachte nur, dass Du ja unendlich viele Menschen kennst, also vielleicht auch Chemiker."

${ }^{76}$ Herman Rechenbergin tämän artikkelin kirjoittajalle sähköpostitse 19.9.2008 antama tieto.
} 
yhdessä, sillä Erwin soitti viulua, ja pelasivat shakkia - jopa kirjeiden välityksellä silloin, kun Erwin oli rintamalla. ${ }^{77}$

Viimeisen kirjeensä Heisenberg kirjoitti Melartinille uudenvuoden 1933 kynnyksellä. Melartin oli oletettavasti lähettänyt hänelle joulutervehdyksen. Tämä 31-vuotias, alle vuoden sisällä Nobel-palkinnon saava fyysikko vastasi siihen Arlbergin hiihtokeskuksesta Itävallasta: "Hyvä Erkki! Küitos ystävällisestä ja minua kohtaan aivan liian mairittelevasta kortistasi. Matkustin nyt yksin ylhäälle lumen pariin ja olen aivan tyytymätön surkeaan hiihtooni täällä. Mutta Suomeen tulisin mielelläni uudelleen. Joten sydämelliset toivotukset uudelle vuodelle!"78

Melartinin kirjeenvaihto muidenkin vuoden 1923 Suomen-matkalla olleiden kanssa päättyi 1930-luvun alussa. Melartinin sekä fyysiset että henkiset voimat olivat kuluneet alituisessa taistelussa kulttuurielämää ja musiikinopetusta kohdanneita vaikeita olosuhteita sekä heikon vastustuskyvyn aiheuttamia monia sairauksia vastaan. Saksalainen yhteiskunta oli elänyt jatkuvia sotien, myllerrysten ja vallankaappausten aikoja ensimmäisestä maailman sodasta, ja Hitlerin valtaannousu 1933 merkitsi demokratian päättymistä. ${ }^{79}$ Partiolaisten sosiaalinen elämä vakiintui pikkuhiljaa, eikä kirjeiden kirjoittamiselle ehkä ollut aikaa. Nobelpalkinto nosti 1933 Heisenbergin saksalaisten tiedemiesten kärkijoukkoon, ja monenlaiset paineet ja huolenaiheet kansallissosialistisessa Saksassa vaikuttivat todennäköisesti osaltaan kirjeenvaihdon hiipumiseen.

Werner Heisenbergilla oli kuitenkin myöhemmin vielä yksi tärkeä linkki Suomeen. Hänen lahjakkaan assistenttinsa Hans Eulerin läheinen ystävä oli teoreettisen fysiikan suuri lupaus, suomalainen Berndt Olof Grönblom, joka myös toimi Heisenbergin yksikössä Leipzigissa. Heisenberg arvosti suomalaista Grönblomia erittäin korkealle, kannusti häntä väitöskirja-aiheen parissa ja oli tekemisissä myös tämän perheen kanssa. Grönholm kaatui jatkosodassa 1941, ja Heisenberg kirjoitti 20-sivuisen kommentaarin tämän kootuista tieteellisistä teoksista Åbo Akademin hänestä 1943 julkaisemaan muistokirjoitukseen. ${ }^{80}$ Myös omaelämäkerrassaan (1969) Heisenberg puhuu sekä Eulerista että Grönblomista, ja jopa Cassidy mainitsee Grönblomin kirjassaan toistaen Heisenbergin koskettavat muistosanat tästä: "Mitä suurenmoisemmat hänen ensi saavutuksensa olivatkaan tieteen alalla, sitä suurempi syy meillä on surra tämän nuoren miehen menetystä, hänet joka yhtäkkiä riuhtaistiin meidän ja työn parista korkeamman velvollisuuden niin kutsuessa." ${ }^{81}$ Grönblomia ja Heisenbergia ei kuitenkaan ole mainittu lainkaan esimerkiksi Marjatta Hietalan tuoreessa monografiassa, jossa on tutkittu suomalais-saksalaisia tiedeyhteyksiä 1800- ja 1900-luvuilla, vaikka sen keskiössä on näkemys siitä, että innovatiivisuus ja innovatiiviset yhteisöt ovat tiiviisti kytköksissä kansainväliseen liikkuvuuteen. ${ }^{82}$

\footnotetext{
${ }^{77}$ Hirsch-Heisenberg 2003, 392.

${ }^{78}$ Kirjeessä 29.12.1932: "Lieber Erkki! Hab herzlichen Dank für Deine freundliche und für mich viel zu schmeichelhafte Karte. Ich reste jetzt allein im Schnee und bin mit meiner schlechten Schifahrerei unzufrieden. Aber nach Finnland käme ich gern wieder. Also die herzlichsten Wünsche zum Neuen Jahr! Dein Werner."

${ }^{79}$ Ks. esim. Hett 2019, 27-41.

${ }^{80}$ Törnqvist 2004, 27; Stenman 2018, 29.

${ }^{81}$ Heisenberg 1971, 176-179; Cassidy 1992, 431-432.

${ }^{82}$ Hietala 2017, 4.
} 


\section{Lopuksi}

Ollessaan vielä koululainen Werner Heisenberg ystävineen kiinnittyi nuorisoliikkeeseen, jonka parissa saadut kokemukset leimasivat hänen koko elämäänsä. Hän sai vartionjohtajana vastuuta itseään nuoremmista jäsenistä retkien suunnittelun ja käytännön toteuttamisen parissa, mutta otti sydämen asiakseen myös heidän henkisen kasvunsa ja vastaamisen heidän filosofisten kysymystensä aiheuttamiin pohdintoihin. ${ }^{83}$ Partion parissa hän itse katsoi kasvaneensa nuorukaisesta mieheksi ja jättäneensä kesällä 1924 lopulliset hyvästit nuoruusvuosille. Tuolloin hän veti viimeistä kertaa retkiä oman ryhmänsä jäsenille ja osoitti lopussa jäähyväissanat kerraten jokaisen kokemukset, kohtalon, kehitysvaiheet, urasuunnitelmat, elämäntilanteen ja suhteen partioaatteeseen. "Werner johdatteli keskustelua aivan upeasti", merkitsi Eberhard Rüdel päiväkirjaansa 1.9.1924. ${ }^{84}$

Partiokokemukset sekä niissä tarvittava rohkeus ja neuvokkuus uusien tilanteiden tai yllättävien pulmien edessä saattoivat olla Heisenbergin etu myös teoreettisessa fysiikassa. Hän kuului Paul Diracin, Wolfgang Paulin ja Pasqual Jordanin kanssa niiden rohkeiden, poikkeuksellisen lahjakkaiden nuorten fysiikanopiskelijoiden valiojoukkoon, jotka kaikista vanhoista rasitteista vapaiden ideoidensa - niin sanotun nappulafysiikan (Knabenphysik) - avulla pystyivät heittämään romukoppaan aikansa eläneet näkökulmat. ${ }^{85} \mathrm{Ja}$ kun Niels Bohr etsi vuoden 1925 lopussa seuraajaa pitkäaikaiselle, hieman turhan varovaiselle yliassistentilleen Hendrik Kramerille, hänen valintansa osui pelottomaan ja jopa uhkarohkeasti seikkailuun tarttuvaan partiolaiseen, nuoreen Göttingenin dosenttiin Werner Heisenbergiin. ${ }^{86}$ Jo vuonna 1927 Bohr ja Heisenberg julkaisivat atomin rakenteen niin sanotun Kööpenhaminan tulkinnan. Sen avulla luotiin perusta kvanttimekaniikalle, jonka ajatuksia ryhdyttiin soveltamaan jo muutaman vuoden päästä.

Kun pyritään ymmärtämään Heisenbergin lahjakkuutta ja hänen elämäntyötään, on hyvä muistaa, ettei niiden perustana ollut kapea-alainen keskittyminen fysiikanopintoihin tai ylipäätään pelkkiin matemaattisluonnontieteellisiin aineisiin. Maxilimians-lyseo oli eliittikoulu, jossa oppilailta vaadittiin paljon ja edellytettiin syvällistä perehtyneisyyttä länsimaiseen humanistiseen perintöön. Nuorisoliikkeen parissa harrastettiin ulkoilun, vuorikiipeilyn, urheilun ja jokamiestaitojen lisäksi kirjallisuutta, filosofiaa, teologiaa, teatteria ja musiikkia. Lähes kaikki Gruppe Heisenbergin jäsenet soittivat jotain klassisen musiikin instrumenttia, ja musiikin esittäminen tai kuuntelu olivat osa illanviettoja ja tapaamisia.

Werner Heisenbergillä oli absoluuttinen sävelkorva, ja hän soitti sekä pianoa, selloa että kitaraa. Pianistina hän oli korkeaa ammattitasoa ja huolehti aina siitä, että hänellä oli mahdollisuus soittaa missä sitten olikaan töissä tai opiskelemassa. Esimerkiksi kirjeessään Melartinille 16.11.1924 Kööpenhaminasta hän kertoi, ettei suinkaan ollut Bohrin instituutissa työskennellessään unohtanut musiikkia. Oikein onnellinen sattuma oli sitä paitsi, että hänen asuintoverinaan pensionaatissa ollut amerikkalainen fyysikko soitti varsin hyvin viulua, niin että heillä oli usein keskenään mukavia hetkiä musiikin parissa.

\footnotetext{
${ }^{83}$ Tämän voi todeta Heinrich Beckerin 2019 kirjassa siteerattujen kymmenien partiotovereille lähetettyjen kirjeiden perusteella.

${ }^{84}$ Rechenberg 2010, 258-259: "Werner leitet sie wunderschön ein."

${ }^{85} \mathrm{Mt} ., 302$.

${ }^{86}$ Mts., 451; Becker 2019, 343
} 
Heisenberg oli ollut jo 13- tai 14-vuotiaana pianonsoitossa sillä tasolla, että pystyi ottamaan haltuun pianokirjallisuuden mestariteokset. ${ }^{87}$ Musiikki ja maailmankirjallisuuden parhaat pianosävellykset tarjosivat oletettavasti Heisenbergille reitin saada syvä tunnetason yhteys itseensä ja muihin sekä kehittää itseään tavalla, jossa emotionaalisten, intellektuaalisten ja motoristen taitojen yhdistyminen itseilmaisuun piti aivot plastisina ja koko kapasiteetin käytössä. Myös se, että kouluikäisenä hän joutui piano-opettajansa vaatimuksesta harjoittelemaan päivittäin tuntikausia, oli varmasti kehittänyt päämäärätietoisuutta ja kykyä ponnistella pitkäjänteisesti halutun tuloksen saavuttamiseksi.

Heisenbergin tytär on muistelmissaan korostanut sitä, miten klassinen musiikki oli elämänalue, joka yhdisti näkymättömällä, mutta kokonaisvaltaisen läsnä olevalla tavalla isää ja lapsia. Jokainen seitsemästä lapsesta soitti jotain instrumenttia, ja kodissa harrastettiin aktiivisesti yhteissoittoa ja kamarimusiikkia. Kotona ollessaan Werner Heisenberg harjoitteli säännöllisesti, yleensä iltaisin. Myös vaimonsa sydämen hän oli valloittanut soittamalla sielukkaasti Beethovenin pianotrion hidasta osaa. ${ }^{88}$

Kohtaaminen Erkki Melartinin kanssa elokuussa 1923 oli lyhyt hetki Heisenbergin elämäntapahtumien virrassa. Ei kuitenkaan ole poissuljettua, etteikö sukulaissielun löytäminen jo kypsempään ikään päässeen, mutta hengeltään poikamielisen ja ihanteellisen Melartinin kanssa olisi voinut olla hyvin merkityksellinen. Melartinin yksi elämäntarkoitus oli kannustaa ja opastaa nuoria kohti kunnianhimoisia päämääriä ja avata heille uusia näköaloja. Aforismikokoelmassaan (1928) Melartin saattoi hyvinkin paljastaa ajatuksensa lähtökohdan: "Korkeasti kehittyneet ihmiset hakeutuvat kernaasti lasten tai hyvin nuorten pariin. Pääasiallisin syy on, että nämä ihmiset elävät oman aikansa edellä, siis etupäässä täysikasvuisten (ja vääräksi kasvaneitten) edellä. Silloin on mahdollisuus, että lapsi, joka edustaa tulevaa, on vaistomaisesti heitä lähempänä, siksi että he henkisesti kuuluvat samaan sukupolveen." ${ }^{89}$ Hans Schmeer katsoi kirjeessään, että myös taiteilijuutensa ansiosta Melartinilla oli kyky ymmärtää toisen ajatuksia ja että hänelle saattoi puhua avoimesti. ${ }^{90}$

Yhteiset kokemukset antoivat myös resilienssiä ja vahvuutta kullekin Gruppe Heisenbergin jäsenelle. Suomen-matkansa kunniaksi he järjestivät saman vuoden joulun aatonaattona pienen yhteisen juhlan, josta edellä mainittu Hans Schmeer kirjoitti Melartinille:

Parhaat kiitokset kiltistä kirjeestäsi - ja ennen kaikkea joulupaketista, josta kaikki Lichtjunget kiittävät minun välitykselläni. Meillä Suomen-matkalaisilla oli pieni herttainen juhla eilen illalla! Ensin herkuttelimme niillä materiaalisilla nautinnoilla, jotka pakettisi meille soi; sitten luin "sinun" Kalevalastasi 50. runoelman ääneen: Marjatta ja Kristuksen syntymä. Werner H. soitti pianosävellyksesi (Dämmerung im Schnee etc.) [opus nro 97 Noli me tangere]. Oli hieno ilta. Ajattelimme sinua ja Suomea ja tunsimme niin kuuluvamme yhteen. ${ }^{91}$

\footnotetext{
${ }^{87}$ Cassidy 1992, 239.

${ }^{88}$ Hirsch-Heisenberg 2003, 351-355, 385. Heisenbergin puhetta ja soittoa on aikoinaan äänitetty ja 2006 koottu kaksois-CD:Ile "Die Verknüpfung von Physik und Philosophie". ks. esim. https://www.adlibris.com/fi/kirja/ die-verknupfung-von-physik-und-philosophie-2-cds-9783932513657.

${ }^{89}$ Melartin 1928, 19; Ranta-Meyer 2008, 77.

${ }^{90}$ Kirjeessä 20.10.1924 Melartinille. Kirjeen kopio kirjoittajan hallussa, sit. myös Becker 2019, 347.

${ }^{91}$ Kirjeessä 24.12.1923: "Lieber Erkki! Besten Dank für Deinen lieben Brief - und vor allem für das Weihnachtspaket, für das Dir einstweilen alle Lichtjungens durch mich danken lassen. Wir hatten eine nette, kleine Feier gestern Abend - wir Finnlandfahrer! Zuerst schwelgten wir im materiellen Genüssen, die uns Dein
} 
Kuva 6. Heisenbergin ja muiden osallistujien nimet Melartinin vieraskirjassa. Valokuva Kansalliskirjasto.

Huippulahjakas Heisenberg ammensi sekä partiotoiminnan että musiikin parissa koettavista syvistä henkisen yhteenkuuluvaisuuden ja samalla aaltopituudella olemisen tunteista myös itse myöhemmin opettajana. Elämänsä loppua kohden hän korosti tohtoriopiskelijansa Helmut Rechenbergin mukaan yhä enemmän sitä, miten tieteen parissa saadut tulokset perustuivat aina sekä tieteelliseen että henkilökohtaiseen dialogiin ihmisten - opettajien, oppilaiden, työntekijöiden ja kollegoiden - välillä. ${ }^{92}$

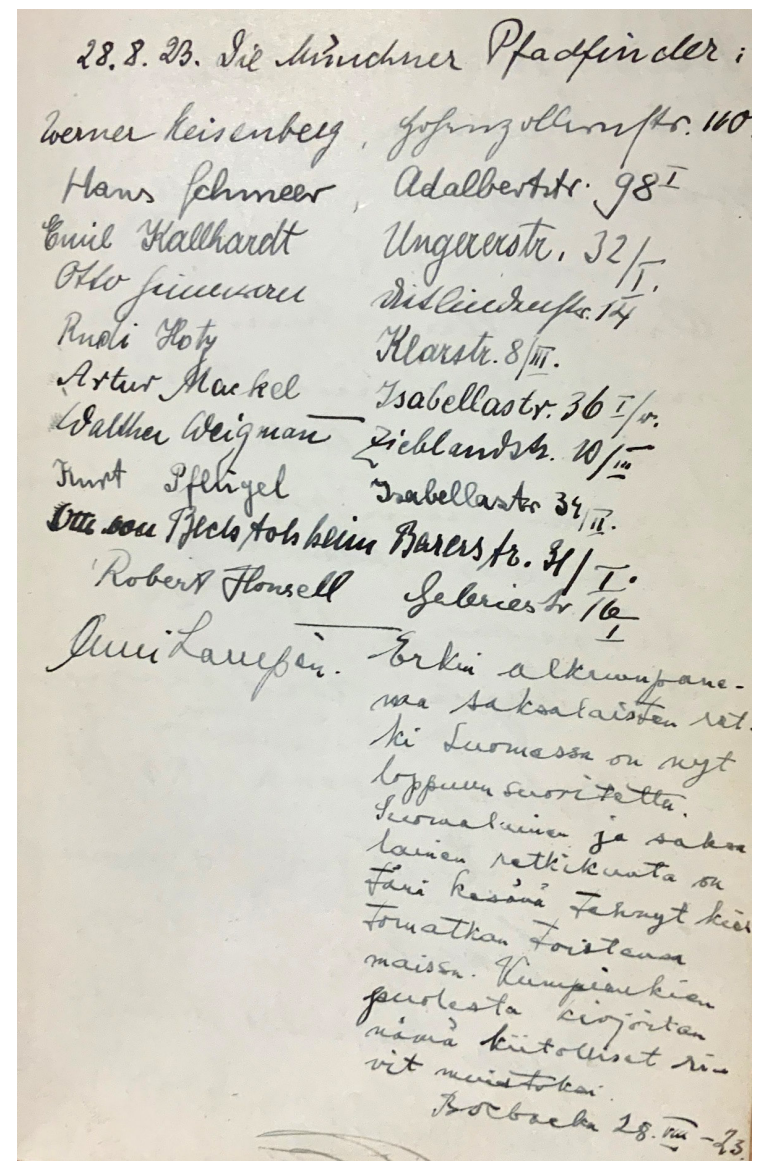

Paket bescherte; dann las ich aus "Deiner" Kalewala die 50. Rune vor: Jungfrau Marjatta u. die Geburt Christi. Werner H. spielte Deine Klavierstücke (Dämmerung im Schnee etc). Es war ein feiner Abend. Wir dachten an Dich u. Finnland u. fühlten uns so zusammehörig." Huom! Melartin sävelsi vuonna 1914 sopraanolle ja orkesterille sävelrunon Marjatta (op. 79), joka perustuu tuohon nimenomaiseen Kalevalan viimeiseen runoelmaan. Ilmeisesti Gruppe Heisenbergin joku jäsen oli saanut tai hankkinut saksankielisen Kalevalan. Kirjeissään Melartinille Gruppe Heisenbergin jäsenet kutsuivat itseään suomalaisten Valon pojat -partiolaisten mukaan nimellä Lichtjungen.

${ }^{92}$ Rechenberg 2010, vii. 


\title{
Lähteet
}

\author{
Arkistolähteet \\ Kansalliskirjasto \\ Erkki Melartinin arkisto Coll.530. \\ Heisenberg, Werner. Kirjeet Erkki Melartinille. \\ Melartin Erkki. Taskukalenteri vuodelta 1923. \\ Pflügel, Kurt. Kirjeet Erkki Melartinille. \\ Schmeer, Hans. Kirjeet Erkki Melartinille. \\ Weigman, Walter. Kirjeet Erkki Melartinille.
}

Muut arkistot

Erkki Melartin. Kirjeet Kurt Pflügelille. Heinrich Beckerin yksityisarkisto. Kopiot käsikirjoituksista Tuire Ranta-Meyerin hallussa.

Werner Heisenberg. Kirje Franz-Ludwig Habbelille 24.9.1923. Heinrich Beckerin yksityisarkisto. Kopio Tuire Ranta-Meyerin hallussa.

\section{Painetut lähteet}

Becker, Heinrich 2019. Die Gruppe Heisenberg. Beitrag zur Geschichte der Jugendbewegung und der Pfandfinder sowie zur Biografie Werner Heisenberg. Omakustanne. Köln: Buch- und Offsetdruckerei Häuser KG.

Bund Deutscher Neupfadfinder. https://de.wikipedia.org/wiki/Bund_Deutscher_Neupfadfinder [Haettu 16.11.2020].

Cassidy, David C. 1992. Uncertainty. The life and science of Werner Heisenberg. New York: W. H. Freeman and Company.

Engman, Max 2000. "Mikrohistoria och livshistoria." Historisk tidskrift för Finland (85): 3, 249-250.

Hakosalo, Heini, Seija Jalagin, Marianne Junila ja Heidi Kurvinen (toim.) 2014. Historiallinen elämä: biografia ja historiantutkimus. Helsinki: SKS.

Heisenberg, Werner 1925. “Über quantentheoretische Umdeutung kinematischer und mechanischer Beziehungen." Zeitschrift für Physik A Hadrons and nuclei 33, 879-8935. Noudettu 15.10.2020 osoitteesta https:// link.springer.com/article/10.1007/BF01328377.

Heisenberg, Werner 1971. Physics and Beyond. Encounters and conversation. Alkuteoksesta Der Teil und das Ganze [1969] englanniksi kääntänyt Arnold J. Pomerans. Lontoo: George Allen \& Unwin Ltd.

Hett, Benjamin Carter 2019. Demokratian kuolema. Kuinka Hitler nousi valtaan. Suom. Tommi Uschanov. Helsinki: WSOY.

Hietala, Marjatta 2001. "Evakkopolulla. Mikrohistoriallinen katsaus Viipurin läänin Johanneksen pitäjän Kaijalan kylän naisten selviytymistarinaan." Teoksessa Ihmisiä, ilmiöitä ja rakenteita historian virrassa. Professori Antero Heikkiselle 60-vuotispäivänä omistettu juhlakirja, s. 245-256. Joensuun yliopiston humanistinen tiedekunta. Hämeenlinna: Karisto.

Hietala, Marjatta 2017. Finnisch-deutsche Wissenschaftskontakte.Zusammenarbeit in Ausbildung, Forschung und Praxis im 19. und 20. Jahrhundert. Berlin: Berliner Wissenschfts-verlag.

Hirsch-Heisenberg, Anna Maria (toim.) 2003. Werner Heisenberg. Liebe Eltern! Briefe aus kritischer Zeit 1918 bis 1945. München: Langen Müller.

Immonen, Kari 2002. "Uusi kulttuurihistoria." Teoksessa Kari Immonen ja Maarit Leskelä-Kärki (toim.): Kulttuurihistoria. Johdatus tutkimukseen, 11-28. 2. painos. Tietolipas 175. Helsinki: SKS.

King, David 2016. Hitlerin oikeudenkäynti. Vallankaappausyritys 1923 ja natsi-Saksan nousu. Suom. Ilkka Rekiaro. Helsinki: Otava.

Leskelä-Kärki, Maarit. 2006. Kirjoittaen maailmassa: Krohnin sisaret ja kirjallinen elämä. Helsinki: SKS.

Leskelä-Kärki, Maarit. 2012. "Samastumisia ja etääntymisiä: elämäkerta historiantutkimuksen kysymyksenä". Teoksessa Tulkinnan polkuja: kulttuurihistorian tutkimusmenetelmiä, toim. Asko Nivala ja Rami Mähkä, 25-48. Turku: Turun yliopisto.

Linnavuori, Johanna 2017. Ihannenuorisoa kasvattamassa. Partioliikkeen arvokasvatus vuosina 1917-1919 Ole Valmis ja Partiolainen -lehtien näkökulmasta. Suomen ja Skandinavian kirkkohistorian pro gradu -tutkielma, Helsingin yliopisto. https://core.ac.uk/download/pdf/84364953.pdf [noudettu 17.11.2020]. 
Melartin, Erkki 1928. Minä uskon -mietelmiä (op. 150). Helsinki: Otava.

Nevanlinna, Rolf 1976. Muisteltua. Helsinki: Otava.

Poroila, Heikki 2016. Erkki Melartinin teosluettelo. Helsinki: Suomen musiikkikirjastoyhdistys.

Ranta-Meyer, Tuire 2008. Nähdä hyvää kaikissa. Erkki Melartin opettajana ja musiikkielämän kehittäjänä. Helsinki: Musiikkikirjastoyhdistys ry.

Raportteeraaja [nimim.] 1920. "Professori Erkki Melartin kutsuttu Valon Poikien veljesritariksi". Partio 1920 nro 12, 190-191.

Rechenberg, Helmut 2010. Werner Heisenberg -Die Sprache der Atome. Leben und Wirken Eine wissenschaftliche Biographie. Die "Fröliche Wissenschaft" (Jugend bis Nobelpreis). Band 1. Heidelberg, Dordrecht, Lontoo, New York: Springer.

Stenman, Folke 2018. "Sherry, Heisenberg och Berndt Olof Grönblom." Arkhimedes 2, 28-29.

Tuominen, Kimmo 2017. “Kvanttimekaniikan synty. Werner Heisenberg”. Tieteessä tapahtuu 2, 20-24.

Törnqvist, Nils A. 2004. “Berndt Olof Grönblom, om blott han fått leva!” Arkhimedes 6, 24-30. 